\title{
The Protective Principle of Jurisdiction over War Crimes and the Hollow Concept of Universality
}

\author{
Matthew Garrod* \\ University of Sussex, United Kingdom
}

\begin{abstract}
At the end of World War II, the prosecution by the Allies of thousands of enemy war criminals in Europe and the Far East, and the creation of International Military Tribunals at Nuremberg and Tokyo, are seen by many as a landmark in the development of international criminal law. This development is widely asserted to have given rise to universal jurisdiction over war crimes for the prosecution of perpetrators of gross human rights offences. By using primary research, the purpose of this article is to challenge the perceived emergence of universal jurisdiction and to show that it has been allowed to develop as a myth, a hollow concept. The article seeks to provide an alternative view, by arguing that jurisdiction over war crimes is better explained as an important development of the protective principle, which was exercised collectively by some Allies, for the punishment of a 'common enemy'.
\end{abstract}

\section{Keywords}

World War II; war crimes; protective principle jurisdiction; universal jurisdiction; role of international law within the international community

\section{Introduction}

At the end of World War II, the prosecution by the Allies of thousands of enemy war criminals in Europe and the Far East, and the creation of International Military Tribunals at Nuremberg and Tokyo, are seen by many as a landmark in the development of international criminal law. This development is widely asserted to have given rise to universal jurisdiction over crimes under international law, including war crimes and crimes against humanity, for the prosecution of perpetrators of gross human rights offences. ${ }^{1}$ This makes universality a relatively new

\footnotetext{
*) I should like to give special thanks to Professor J. Craig Barker for his guidance, comments and inspiration; I am grateful for the constructive comments by the anonymous reviewer.

1) The literature is too numerous to cite, but see Eichmann v. Attorney-General, 36 ILR 277 (Supreme Court), pp. 293-300; Demjanjuk v. Petrovsky, 776 F. 2d 571 (6th Cir. 1985), p. 582; Polyukhovich v. Commonwealth (1991) 101 ALR 545; U.S. v. Yousef, 327 F2d 56 (2nd Cir. 2003); American Law Institute, 'Restatement of the Law (Third) of Foreign Relations Law of the United States', (1987) para. 404; International Law Association, London Conference, 'Final Report on the Exercise of
} 
development in international law; moreover, the legitimacy of this concept under current international law is regarded by many courts and commentators as being dependent upon the trial of war criminals in the aftermath of World War II. ${ }^{2}$ Although a great deal of work to clarify universal jurisdiction has been undertaken in recent years, there is neither a consensus on what universal jurisdiction is or should be, nor a consensus regarding the crimes covered by the concept, either in doctrine or State practice. ${ }^{3}$ However, it has been suggested to be based solely on the 'heinous' nature of the crime, the suppression of which is a concern of the international community. ${ }^{4}$ Thus, according to a resolution adopted in

Universal Jurisdiction in Respect of Gross Human Rights Offences', (2000) pp. 3, 22; Thomas H. Sponsler, 'The Universality Principle of Jurisdiction and the Threatened Trials of American Airmen', 15 Loyola Law Review (1968-1969) p. 49; Michael Akehurst, 'Jurisdiction in International Law', 46 British Yearbook of International Law (1974) p. 160; Kenneth Randall, 'Universal Jurisdiction', 66 Texas Law Review (1987-1988) pp. 802-810; Theodore Meron, 'International Criminalisation of Internal Atrocities', 89 American Journal of International Law (1995); Theodore Meron, 'Is International Law Moving Towards Criminalisation?', 9 European Journal of International Law (1998); Chris C. Joyner, 'Arresting Impunity: The Case for Universal Jurisdiction in Bringing War Criminals to Accountability', 59 Law and Contemporary Problems (1996) pp. 155-156, 166, 172; Sharon A. Williams, 'Laudable Principles Lacking Application: The Prosecution of War Criminals in Canada', in Timothy L.H. McCormack and Gerry J. Simpson (eds.), The Law of War Crimes. National and International Approaches (Kluwer, London, 1997) p. 162; Luc Reydams, Universal Jurisdiction. International and Municipal Perspectives (Oxford University Press, Oxford, 2005) p. 34; Michael P. Scharf, 'Application of Treaty-Based Universal Jurisdiction to Nationals of Non-State Party States', 35 New England Law Review (2000-2001) p. 369; Madeline H. Morris, 'Universal Jurisdiction in a Divided World: Conference Remarks', 35 New England Law Review (2001) pp. 344-345; Bruce Broomhall, International Justice and the International Criminal Court (Oxford University Press, Oxford, 2003) p. 112; Anthony Sammons, "The "Under-Theorisation" of Universal Jurisdiction: Implications for Legitimacy on Trials of War Criminals by National Courts', 21 Berkley Journal of International Law (2003) p. 125-126; Eugene Kontorovich, 'Universal Jurisdiction and the Piracy Analogy', 45 Harvard International Law Journal (2004) pp. 185, 194195; James P. Benoit, 'The Evolution of Universal Jurisdiction over War Crimes', 53 Naval Law Review (2006) p. 264; Mark Chadwick, 'Modern Developments in Universal Jurisdiction: Addressing Impunity in Tibet and Beyond', 9 International Criminal Law Review (2009) p. 362; Anja Matwijkiw, 'The No Impunity Policy in International Criminal Law: Justice versus Revenge', 9 International Criminal Law Review (2009); Maximo Langer, 'The Diplomacy of Universal Jurisdiction: The Political Branches and the Transnational Prosecution of International Crimes', 105 American Journal of International Law (2011) p. 3.

2) Ibid.

3) Arrest Warrant of 11 April 2000 (Congo v. Belgium), ICJ Reports 2002, per Dissenting Opinion of Judge van den Wyngaert, p. 166, <www.icj-cij.org/>, 20 April 2012; Report of the SecretaryGeneral prepared on the basis of comments and observations of governments, The Scope and Application of the Principle of Universal Jurisdiction (29 July 2010) (U.N. Doc. A/65/181) (hereafter S-G Report).

4) Arrest Warrant, ibid., per Joint Separate Opinion of Judges Higgins et al., p. 82; per Dissenting Opinion of Judge van den Wyngaert, ibid., p. 167; S-G Report, ibid., p. 4; Council of the European Union, AU-EU Technical ad hoc Expert Group, Report on the Principle of Universal Jurisdiction, Final Report (16 April 2009) (Doc. 8672/1/09 REV 1), para. 9, <www.universaljurisdiction.org/ images/reports/publications/au_eu_expert_report.pdf>, 20 April 2012 (hereafter AU-EU Expert Group); Princeton University Program in Law and Public Affairs, The Princeton Principles on 
2005 by the Institute of International Law, certain crimes under international law may be prosecuted by any State whatever, having no connection at all with the offence, and in the absence of any other bases of jurisdiction recognised by international law. ${ }^{5}$

Although universal jurisdiction is generally stagnant in State practice, in recent years, the attempt made by a handful of almost exclusively European States to use this principle in order to justify proceedings against incumbent State officials accused of human right offences in foreign countries has "led to misunderstandings, escalation of inter-State tensions and given rise to perceptions of abuse on political or other grounds" ${ }^{6}$ What is more, since 2009, the scope and application of universal jurisdiction has been the subject of heated debate before the U.N. General Assembly and the Sixth Committee, after complaints by African States that the principle was being abused. ${ }^{7}$ The essence of this debate is a perceived conflict between two values in modern international law: preventing the impunity of the perpetrators of 'heinous' crimes under international law, on the one hand, and protecting the principles of sovereignty and sovereign equality and independence and the immunity of incumbent State officials before foreign criminal jurisdictions, on the other. ${ }^{8}$

As no precedent existed prior to World War II for universal jurisdiction over crimes under international law, ${ }^{9}$ and given that it is perhaps the most controversial concept of extraterritorial jurisdiction, it is rather surprising that the principle's supposed origins have not received closer scrutiny.

Universal Jurisdiction, p. 45, <www.princeton.edu/-lapa/unive-jur.pdf>, 10 April 2012 (hereafter Princeton Principles).

5) Institut de Droit International, Resolution on Universal Criminal Jurisdiction with Regard to the Crime of Genocide, Crimes Against Humanity and War Crimes, adopted in Krakow, 2005, <www .idi-iil.org/idiF/resolutionsF/2005_kra_03_fr.pdf>, 10 April 2012; AU-EU Expert Group, ibid., para. 8.

6) International Law Commission, Immunity of State Officials from Foreign Criminal Jurisdiction (U.N. Doc. A63/10), para. 283; Arrest Warrant, supra note 3.

7) African Union, The Executive Council, Report of the Commission on the Use of the Principle of Universal Jurisdiction by some Non-African States as Recommended by the Conference of Ministers of Justice/Attorneys General (June 2008) (Doc. EX.CL/411(XIII)), <www.africa-union.org/root/au/ Conferences/2009/july/summit/decisions/ASSEMBLYAUDEC243-267 (XIII)_e.pdf>, 1 April 2012; Decision of Assembly of the African Union on the Report of the Commission on the Abuse of the Principle of Universal Jurisdiction (June/July 2008) (Doc. Assembly/AU/Dec.199 (XI)), <www .africa-union.org/root/au/conferences/2008/june/summit/dec/ASSEMBLYDECISIONS193 -207(XI).pdf>, 4 April 2012; AU-EU Expert Group, supra note 4, para. 19; U.N. General Assembly resolution, The Scope and Application of the Principle of Universal Jurisdiction (Official Records of the General Assembly, 64th Session, U.N. Doc. A/63.PV.105); S-G Report, supra note 3.

8) See Arrest Warrant, supra note 3, per Joint Separate Opinion of Judges Higgins et al.; per Dissenting Opinion of Judge van den Wyngaert, ibid., p. 142.

9) Although piracy is widely asserted as a crime under international law and subject to universal jurisdiction, this remained disputed until at least a decade after World War II; see Geneva Convention on the High Seas 1958, Article 19, restated in United Nations Convention on the Law of the Sea 1982, Article 105. 
The purpose of this article is to challenge the generally accepted view, by using primary source material, including the reports of trials prepared by the United Nations War Crimes Commission (hereafter UNWCC), that the trial of war criminals in the aftermath of World War II gave rise to universal jurisdiction. ${ }^{10}$ In so doing, the article aims to shed new light on the historical background of the current debate about the principle of universal jurisdiction. As will be shown, the development of universal jurisdiction has been accepted uncritically, and often exaggerated, by courts and commentators, which have persistently either relied on tentative, secondary material, or cited primary materials, wholly out of context. This article provides an alternative view, by arguing that jurisdiction over war crimes may be better explained as an important development of the protective principle. The protective principle is little understood and has never before been examined in relation to crimes under international law. There is no accepted definition of the protective principle either in doctrine or State practice, although it is often suggested to permit States under international law to exercise jurisdiction over crimes committed by foreign nationals outside of their territory which threaten their vital interests. The principle's rationale is thus based on the necessity to protect vital State interests, including sovereignty, security, political independence and governmental functions. ${ }^{11}$ As will be explained, in the context of the aftermath of World War II, what was often perceived to be universality was in fact as expanded principle of protective jurisdiction, which was exercised by some of the Allies collectively, for the punishment of a 'common enemy'. The article proposes that there is therefore a crucial conceptual distinction to be made as to the basis of jurisdiction over war crimes, between the protection of certain vital State interests, which are shared by the international community and protected by international law, and universality. This reconceptualisation of jurisdiction over war crimes, it is submitted, reflects more accurately the proper role of international law within the international community.

The article begins by examining the supposed rise of universal jurisdiction over war crimes immediately after World War II. Thereafter, it examines the jurisdiction of the military tribunals established by the so-called 'Great Powers'-Britain, United States, Soviet Union and France-within their respective zones of occupied Germany for the prosecution of war crimes, crimes against humanity and crimes against peace and shows that jurisdiction was far from 'universal'. The third part of the article explains that the scope of jurisdiction over these crimes was restricted to persons belonging to a 'common enemy' engaged in a State policy of aggressive

10) History of the United Nations War Crimes Commission and the Development of the Laws of War (HMSO, London, 1948) (hereafter History); Law Reports of the Trials of War Criminals. Selected and Prepared by the United Nations War Crimes Commission, vols. I-XV (HMSO, London, 1947-1949) (hereafter Law Reports).

11) See Ian Cameron, The Protective Principle of International Criminal Jurisdiction (Dartmouth, Aldershot, 1994). 
war. The article then goes on to examine the right under international law to prosecute crimes under international law and suggests that it has traditionally been restricted to that of injured States, which was recognised as such by the Allies at the end of World War II. As will be explained, jurisdiction over war crimes was based on the protective principle, which was justified as part of a broader right of self-defence. The article then shows that the protective principle was expanded by some of the Allies and, in some cases, exercised collectively, which is perhaps best illustrated by the International Military Tribunals in Nuremberg and Tokyo. Finally, on the basis of State practice in the aftermath of World War II, the article proposes that there is a crucial distinction to be made as to the basis of jurisdiction over war crimes, between the protection of vital State interests, which are shared by international community, and universality.

\section{The 'Rise' of Universal Jurisdiction over Crimes under International Law}

The trials of war criminals after World War II in Europe and the Far East, aside from the principles of territoriality and nationality, concerned the exercise of jurisdiction by the Allies over crimes committed abroad by persons belonging to the 'enemy' in two general situations: the first of these was the prosecution by a belligerent of war crimes or crimes against humanity against their own or Allied nationals; the other was the prosecution by several of the Allied belligerents in enemy territory of crimes against peace and war crimes against themselves or other Allies, and crimes against humanity committed against German nationals and stateless persons on German territory. ${ }^{12}$ These war crimes trials have been widely asserted as the rise of universal jurisdiction over crimes under international law. ${ }^{13}$ In support, courts and commentators have argued that universal jurisdiction has developed historically over piracy because it is a 'heinous' crime, which was extended by the Allies to cover equally heinous crimes other than piracy. ${ }^{14}$ The analogy between war crimes and piracy was first made formally by

12) E.g., see The Zyklon B Case, Law Reports, vol. I, p. 103; The Hadamar Trial, Law Reports, vol. I; The Belsen Trial, Law Reports, vol. II; The Justice Trial, Law Reports, vol. VI; The Krupp Trial, Law Reports, vol. X; The Dachau Concentration Camp Trial, Law Reports, vol. XI; The German High Command Trial, Law Reports, vol. XII; Law Reports, vol. XV, p. 43; In re Ohlendorf and Others, 15 ILR 656.

13) Supra note 1.

14) Memorandum Submitted by the Secretary-General, The Charter and Judgment of the Nuremberg Tribunal: History and Analysis (1949) (U.N. Doc. A/CN.4/5) p. 80; Eichmann, supra note 1; Demjanjuk, supra note 1; The Prosecutor v. Dusco Tadic, Decision on the Defence Motion for Interlocutory Appeal on Jurisdiction, Case No. IT-94-1-AR72, para. 57; Rv. Bartle and Commissioner of Police for the Metropolis and Others, ex parte Pinochet; $R v$ Evans and Commissioner of Police for the Metropolis, ex parte Same (Amnesty International and Others intervening), per Lord BrowneWilkinson, p. 9; per Lord Millett, ibid., pp. 70-71; Quincy Wright, 'War Criminals', 39 American 
the UNWCC. Lord Wright, the eminent jurist and head of the UNWCC, after purportedly examining the trials of war criminals, came to the following conclusion:

According to generally recognised doctrine $[\ldots]$ the right to punish war crimes is not confined to the State whose nationals have suffered or on whose territory the act took place but is possessed by any independent State whatever, just as is the right to punish the offence of piracy ... [E]very Independent State has in International Law jurisdiction to punish pirates and war criminals in its custody regardless of the nationality of the victims or the place where the offence was committed $\ldots{ }^{15}$

Lord Wright thus endorsed the principle of universal jurisdiction over war crimes, by invoking a supposedly analogous right of universality over piracy as a justification. In support of the existence of universal jurisdiction, as well as its aforesaid definition, which according to Lord Wright was a "generally recognised doctrine", he relied not upon existing State practice, but, rather surprisingly, on academic commentary by Cowles. ${ }^{16}$

Cowles was a Lieutenant-Colonel of the Judge Advocate General's Department for the U.S. and he is regarded as coining the term 'universal jurisdiction'. ${ }^{17}$ Importantly, in his article, Cowles declared that his argument for universal jurisdiction over war crimes was not the view of the U.S. Government. However, in a separate article published three years later by Cowles, he made the following declaration, as to his doctrine of universal jurisdiction, which is revealing:

It was put forward first in the form of a memorandum made available to the United Nations War Crimes Commission in the autumn of 1944. At the suggestion and with the personal

Journal of International Law (1947) pp. 280-283; Eric S. Kobrick, 'The Ex-Post Facto Prohibition and the Exercise of Universal Jurisdiction Over International Crimes', 87 Columbia Law Journal (1987); Hari M. Osofsky, 'Domesticating International Criminal Law: Bringing Human Rights Violators to Justice', 107 Yale Law Review (1997) pp. 193, 205-207; Mark R. von Sternberg, 'A Comparison of the Yugoslavian and Rwandan War Crimes Tribunals: Universal Jurisdiction and the "Elementary Dictates of Humanity", 22 Brooklyn Journal of International Law (1996-1997) pp. 133-134, 151; Leila N. Sadat, 'Redefining Universal Jurisdiction', 35 New England Law Review (2000-2001) pp. 244-245; Mahmoud C. Bassiouni, 'Universal Jurisdiction for International Crimes: Historical Perspectives and Contemporary Practice', 42 Virginia Journal International Law (2001-2002) p. 99; Kerry C. O’Neil, 'A New Customary Law of Head of State Immunity? Hirohito and Pinochet', 38 Stanford Journal of International Law (2002) pp. 295-298; Gabriel Bottini, 'Universal Jurisdiction After the Creation of the International Criminal Court', 36 International Law and Politics (2004) pp. 530-531, 549-550; Robert Cryer et al., An Introduction to International Criminal Law and Procedure (Cambridge University Press, Cambridge, 2007) p. 45; Malcolm N. Shaw, International Law (Cambridge University Press, Cambridge, 2008) pp. 668-689; Joyner, supra note 1, p. 168; Kontorovich, supra note 1, p. 195; Morris, supra note 1, p. 345; Randall, supra note 1, pp. 803-804; Scharf, supra note 1, pp. 369-371; Cowles, infra note 13, p. 194.

15) Law Reports, vol. XV, p. 26, citing Willard B. Cowles, 'Universality of Jurisdiction over War Crimes', 33 California Law Review (1945); see also Lord Wright, Law Reports, ibid., p. x.

16) Ibid.

17) International Law Association, supra note 1, p. 3. 
encouragement of Sir Cecil Hurst, then Chairman of the United Nations War Crimes Commission, that paper was expanded in London and Washington during the winter of 1944-1945. The following spring, the ribbon copy of this larger paper was turned over to Mr Justice Jackson's staff, and a carbon copy used for its publication in the June issue of the California Law Review. ${ }^{18}$

As indicated, it would appear that the argument made by Cowles was accepted by the UNWCC, including its U.S. representatives, as well as by the U.S. prosecution department, even though it was not based on State practice; rather, Cowles had proposed universal jurisdiction de lege ferenda and he was seeking to justify the trial of war criminals in the aftermath of World War II. The argument made by Cowles in support of universal jurisdiction over war crimes is, at best, tenuous and, at worst, flawed. Before examining his argument, it should be noted that Cowles claimed to examine the right of 'every' State to exercise universal jurisdiction over war crimes; however, on closer inspection, his analysis was of a much more limited scope, and concerned the question as to whether "under international law, a belligerent State has jurisdiction to punish an enemy war criminal in its custody when the victim of the war crime was a national of another State and the offense took place outside of territory under control of the punishing State". ${ }^{19}$ Although it was not admitted by Cowles, the right under international law to which he was referring was that of a "belligerent State" to prosecute war crimes "by an enemy" against the nationals of an Allied belligerent in one and the same war. As will be explained below, this is not universal jurisdiction at all.

The first argument made by Cowles in support of universal jurisdiction over war crimes was that international law does not impose any limitation upon a State from exercising jurisdiction over foreign nationals abroad. In support of this argument, Cowles relied uncritically upon the Lotus case. ${ }^{20}$ It will be recalled that the Permanent Court of International Justice in that case ultimately relied upon the principle of objective territorial jurisdiction and it did not, in fact, decide in favour of the extreme proposition that any State is permitted to exercise its criminal jurisdiction over any conduct of any foreign nationals abroad, unless prohibited by international law. ${ }^{21}$ If international law did not impose any limitations on the use and scope of a State's criminal jurisdiction, then it would be of little

\footnotetext{
18) Willard B. Cowles, 'Trials of War Criminals (Non-Nuremberg)', 42 American Journal of International Law (1948) p. 312.

19) Cowles, supra note 15, p. 178.

20) Ibid.

21) E.g., see the anonymous note on the Lotus case in British Yearbook of International Law 9 (1928) p. 134; A. R. Carnegie, 'Jurisdiction over Violations of the Laws and Customs of War', 39 British Yearbook of International Law (1963) pp. 403-406; Rosalyn Higgins, Problems \& Process. International Law and How We Use it (Clarendon, Oxford, 1995) p. 77; Vaughn Lowe, 'Jurisdiction', in Malcolm D. Evans, (ed.), International Law (Oxford University Press, Oxford, 2003) p. 335.
} 
practical value to speak of permissible principles of international law to prescribe, which have long been recognised in doctrine and State practice. ${ }^{22}$

Cowles took his analysis one step further and argued that universal jurisdiction must exist, as opposed to any other principle of jurisdiction, over war crimes. To support this argument, Cowles argued that war crimes are analogous to piracy on the high seas, which has historically been subject to universal jurisdiction in order to prevent such crimes from being committed with impunity. According to Cowles, universal jurisdiction is applicable over war crimes, as ordinary law enforcement during hostilities is difficult or suspended and all nations have an interest in punishing crimes under international law. ${ }^{23}$ However, Cowles did not provide any evidence of State practice of universal jurisdiction over war crimes. Despite noting that "the state whose nationals are affected has a primary interest" in the punishment of war crimes and acknowledging that "most war crimes in the present war [World War II] have been committed 'against the security of the United Nations'", Cowles concluded that, under the doctrine of universality, "every independent state has jurisdiction to punish war criminals in its custody". ${ }^{24}$

The argument made by Cowles in support of the development of universal jurisdiction over war crimes, by analogising them with piracy, is flawed for two important reasons. First and foremost, it is based entirely upon the assumption that universal jurisdiction has historically developed over piracy; the origins, and, indeed, the very legitimacy, of universal jurisdiction are dependent upon piracy. ${ }^{25}$ Although it is beyond the endeavours of the present article, it suffices to say that jurisdiction has historically developed over piracy under the protective principle. ${ }^{26}$ What is more, piracy was described as being 'heinous' because it constituted the waging of unlawful warfare against the colonial trade of sovereigns, which has nothing at all to do with the way in which war crimes, crimes against humanity and other human rights offences are described as being heinous by courts and commentators seeking to expand universality to include crimes other than piracy. ${ }^{27}$ Secondly, piracy could historically be committed by persons who were not sanctioned by any State; it is precisely for this reason why jurisdiction developed over piracy, as it provided the maritime powers with a mutually beneficial

22) James L. Brierly and Charles De Visscher, 'Jurisdiction over Extraterritorial Crime', 26 American Journal of International Law (Spec. Supp.) (1926); Research on International Law Under the Auspices of the Harvard Law School, Part II, 'Jurisdiction with Respect to Crime', 29 American Journal of International Law (Supp.) (1935).

23) Cowles, supra note 15, p. 194.

24) Ibid., p. 218.

25) Princeton Principles, supra note 4, p. 45; Arrest Warrant, supra note 3, per Joint Separate Opinion of Judges Higgins et al., p. 82.

26) Garrod. M. 'Piracy, the Protection of Vital State Interests and the False Foundations of Universal Jurisdiction in International Law' (Working Paper).

27) Ibid. See also Kontorovich, supra note 1. 
right of protection, on the one hand, and it did not interfere with their own sovereign rights on the high seas, on the other. ${ }^{28}$ The same reasoning does not apply to war crimes, as well as crimes against peace and crimes against humanity, which were carried out during World War II as part of official State policy. This very point was made at the end of World War I by the 'Committee of Enquiry into the Breaches of the Laws of War' ${ }^{29}$ There is one final issue: Cowles assumed that crimes under international law are ipso facto subject to universal jurisdiction; in doing so, he also conflated the distinction as to the basis of jurisdiction over war crimes between the protection of vital State interests, which are shared by the international community, and universality. ${ }^{30}$ This crucial distinction will be returned to below.

The reliance by Lord Wright on the article by Cowles led him to misinterpret the basis of jurisdiction over war crimes. Lord Wright also sought to justify universal jurisdiction over war crimes by asserting that it had "received the support" of the UNWCC. ${ }^{31}$ The Allied military courts and tribunals involved in the prosecution of enemy war criminals did not, as a general rule, deliver reasoned judgments or specify the basis of their jurisdiction over the accused. ${ }^{32}$ In fact, in the handful of cases where universality is referred to as one of the possible bases of jurisdiction over war crimes, it is stated not in the actual judgments of these cases, but, rather, in the reports of these cases prepared by the UNWCC..$^{33}$ However, the reasoning of the UNWCC for interpreting these cases as based on universality is not persuasive either. This is illustrated by The Almelo Trial. In that case, a British military court sitting in the Netherlands convicted German defendants for the murder of a British soldier and a Dutch civilian in the Netherlands. As regards the former crime, the report of the UNWCC stated that jurisdiction was based on the victim as a "member of the British Armed Forces", which, as will be explained below, was based on the protective principle of jurisdiction. As regards the latter crime, it was suggested that:

under the general doctrine called Universality of Jurisdiction over War Crimes, every independent state has in International Law jurisdiction to punish pirates and war criminals in its

28) Ronald Roxburgh, 'Submarines at the Washington Conference', 3 British Yearbook of International Law (1922-1923) p. 154; Carnegie, supra note 21, p. 421; Morris, supra note 1, pp. 339-340; David W. Bowett, 'Jurisdiction: Changing Patterns of Authority over Activities and Resources', 53 British Yearbook of International Law (1982) p. 12.

29) 'First, Second and Third Interim Reports from the Committee of Enquiry into Breaches of the Laws of War, with Appendices', 26 February 1920, National Archives, cab/24/111, p. 19; see also Hugh H. L. Bellot, 'War Crimes: Their Punishment and Prevention', 2 Problems of War (1916) p. 43.

30) See Lord Wright, Law Reports, vol. XV, p. 26, citing Cowles.

31) Ibid.

32) Ibid., p. 20; see also International Law Association, supra note 1, p. 22.

33) Law Reports, vol. I, p. ix. 
custody regardless of the nationality of the victim or the place where the offence was committed. ${ }^{34}$

Surprisingly, UNWCC's report of that case does not provide any evidence of this "general doctrine called Universality of Jurisdiction over War Crimes"; nor does it explain the relationship between war crimes and piracy. It is thus not clear the basis upon which the UNWCC found universality over war crimes to exist. What is more, there is nothing in the reasoning of the court in the Almelo Trial to suggest that it even recognised the existence of universality. The report of the Almelo Trial is no different from the two other cases where universality is interpreted by the UNWCC as one of the possible bases of jurisdiction over war crimes. ${ }^{35}$ Notably, although it was not admitted by the UNWCC, it relied in support of universal jurisdiction upon the article by Cowles, which had also been relied upon by Lord Wright. ${ }^{36}$ Crucially, the UNWCC did not give sufficient consideration of the fact that the right of British military courts to sit in Dutch territory in the Almelo Trial, as with military courts and tribunals set up by the Allies in former enemy occupied territories more generally, was based on an agreement between Dutch and British authorities for the prosecution of war crimes by the 'enemy' against British and Allied nationals in one and the same war. ${ }^{37}$ Moreover, the defendants in the Almelo Trial were tried under the British Royal Warrant which, as will be explained below, did not provide for universal jurisdiction. Of importance to the exercise of jurisdiction over war crimes in the Almelo Trial was the status of the victims as 'Allied' nationals and of the accused as belonging to the 'enemy'.

The UNWCC and Lord Wright accepted uncritically and without any evidence the concept of universal jurisdiction over war crimes, by relying wholly upon the article by Cowles. This, in turn, raises a preliminary yet profound question, and one that has to date been overlooked, namely the reason why the UNWCC and Lord Wright felt compelled to readily accept Cowles' argument of universal jurisdiction over war crimes. What is more, Cowles' analogy of war criminals with pirates was even adopted by the U.S. Government and used by Justice Robert Jackson, Chief of Counsel for the U.S. and Chief Prosecutor before the International Military Tribunal at Nuremberg, in support of jurisdiction over

\footnotetext{
34) Ibid., p. 42.

35) The Hadamar Trial, Law Reports, vol. I, p. 53; The Zyklon B Case, Law Reports, vol. I, p. 103.

36) This is declared as such by Cowles, supra note 18, p. 312 .

37) The agreement between the Dutch and British authorities is referred to in the Preamble to the Dutch Law-Decree of 23rd August, 1944 (No. E.66). See also Ian Campbell, 'Some Legal Problems Arising out the Establishment of the Allied Military Courts in Italy', 1 International Law Quarterly (1947) pp. 195-196.
} 
enemy war criminals for crimes under international law. ${ }^{38}$ This has important implications, particularly as the UNWCC's work was declared to have "great influence upon the moulding of international criminal law and the basis of jurisdiction over war crimes" ${ }^{39}$ Moreover, courts and commentators have accepted uncritically the reports and conclusions of the UNWCC as a precedent for the application of universal jurisdiction over war crimes and other crimes under international law. It has also led to the mistaken assumption that international law has as its role the suppression of crimes under international law to protect the values of the international community. ${ }^{40}$ The sections that follow examine jurisdiction during the war crimes trials and seek to demonstrate that it is better explained under the protective principle.

\section{The Prosecution of War Criminals under Control Council Law No. 10}

The vast majority of war crimes trials at the end of World War II, which also happen to be cited most often by commentators in support of universal jurisdiction, were undertaken not by the International Military Tribunals at Nuremberg and Tokyo for the prosecution of 'major' war criminals, but, rather, by domestic military tribunals set up by the Great Powers within their respective zones of occupied Germany, acting under Law No. 10 of the Allied Control Council for Germany (Law No. 10). ${ }^{41}$ It is useful therefore to examine Law No. 10 and the jurisdiction of the Great Powers under this agreement. The Control Council for Germany, which was comprised of the Great Powers, enacted Law No. 10, which had as its purpose, according to its Preamble, first, to "give effect" to the Moscow Declaration and the London Agreement, and, second, "to establish a uniform legal basis in Germany for the prosecution of war criminals ... other than those dealt with by the International Military Tribunal." The acts "recognised as a crime" by Law No. 10 were crimes against peace, war crimes, crimes against humanity and membership of a group declared criminal by the Nuremberg Tribunal. ${ }^{42}$ As regards the scope of Law No. 10, Article III provided that "Each occupying authority, within its zone of occupation, shall have the right to cause persons within such zone suspected of having committed a crime, including those

\footnotetext{
38) International Conference on Military Trials, London, 1945, Report to the President by Mr. Justice Jackson, 6 June 1945, The Avalon Project. Documents in Law, History and Diplomacy, <www.avalon.law.yale.edu/subject_menus/imt.asp>, 20 March 2012; see also Justice Jackson's Opening Statement for the Prosecution at Nuremberg, 21 November 1945, Nuremberg Trial Proceedings, vol. II, ibid., p. 148.

39) Law Reports, vol. XV, p. 22.

40) Infra.

41) Law relating to the punishment of persons guilty of war crimes, crimes against peace and crimes against humanity, enacted at Berlin on 20 December 1945.

42) Ibid., Article II(1).
} 
charged with a crime by one of the United Nations, to be arrested" ${ }^{43}$ It will be noted that the jurisdiction of each of the Great Powers was restricted to persons "within its zone of occupation", for crimes committed both within and outside of Germany, either against themselves or any of the "United Nations". An exception to this was jurisdiction over crimes against humanity, which was restricted even further to crimes committed within Germany "by persons of German citizenship or nationality against other persons of German citizenship or nationality, or stateless persons". ${ }^{44}$ Although the persons subject to Law No. 10 were, according to Article II(2), "[a]ny person without regard to nationality", this was in effect restricted to persons belonging to the 'enemy'. This is affirmed, in addition to the Preamble, by Article I, which declared that "integral" to Law No. 10 are the Moscow Declaration, "Concerning Responsibilities of Hitlerites for Committed Atrocities", and the London Agreement, "Concerning Prosecution and Punishment of Major War Criminals of the European Axis". ${ }^{45}$ That Law No. 10 was restricted to the punishment of persons belonging to the 'enemy' was also the view of Lord Wright. ${ }^{46}$ Finally, Law No. 10 was limited temporally to crimes committed between 30 January 1933 and 1 July $1945 .{ }^{47}$

Law No. 10 was an inter-Allied agreement between the Great Powers governing the right to set up military tribunals for the trial and punishment of war criminals in Germany. However, in order to prosecute crimes under Law No. 10, the Great Powers also had to provide for jurisdiction under their own municipal law. The jurisdiction of British military courts for the trial and punishment of war crimes arising out of World War II was based on the Royal Warrant of 14 June 1945, which was an exercise of Royal Prerogative. ${ }^{48}$ Notably, prior to the creation of the Warrant, it was abruptly realised by the British Government, at the end of the war, due to a reluctance to try enemy war criminals, that there existed under English municipal law no right for British courts to exercise jurisdiction over war crimes committed by foreign nationals outside of British territory, "even though the crime be committed against a British subject". ${ }^{49}$ This meant that war crimes by the "enemy" during the "present war" against British and Allied nationals in Europe and on the high seas could not be tried due to the lack of

\footnotetext{
43) Ibid., Article III (1)(a). The meaning of 'United Nations' is a reference to the Allied nations at war with the Axis Powers and is not related to the international organisation of that name which came into being at San Francisco.

44) Ibid., Article 3(1)(d).

45) See also Article II(5), ibid.

46) History, supra note 10, p. 318; see also The Justice Trial, Law Reports, vol. VI.

47) Supra note 41, Article 2(5).

48) Army Order 81/1945. For discussion of the British Royal Warrant, see Law Reports, vol. I, Annex I; A. P. V. Rogers, 'War Crimes Trials under the Royal Warrant: British Practice 1945-1949', 39 International Comparative Law Quarterly (1990).

49) War Cabinet, 'War Crimes Bill', 2 October 1944, National Archives, cab/55/50.
} 
jurisdiction. ${ }^{50}$ It was therefore suggested that "in conformity with the Law of Nations His Majesty has an undoubted right to authorise the trial and punishment of violations of the laws and usages of war", either in Britain or "any other place", which are "committed during any war in which He may be engaged". ${ }^{51}$ It was believed that the most appropriate way for Britain to try members of the enemy who had committed war crimes against "British subjects" was to set up military courts to try them in Germany "or any other place". ${ }^{52}$ The jurisdiction of British military courts under the terms of the Warrant was explained in the trial of Gustav Alfred Jepson, which concerned the prosecution of a Danish and two German nationals charged with the ill-treatment and killing of various 'Allied' nationals. The Prosecutor in that case explained that "war crimes" in the British zone means "any violation of the usages of war committed either by the Germans or by any person in German employ in which the victims were British or Allied nationals $[. .$.$] during any war in which His Majesty has been or may be engaged$ any time since the 2 nd September, 1939". ${ }^{53}$

The first thing to note is that the jurisdiction of British military courts was not universal, which is clear from the reference to "any war in which His Majesty has been or may be engaged". Accordingly, British military courts did not have jurisdiction over war crimes arising out of a war in which Britain was not engaged. ${ }^{54}$ The Warrant conferred upon British military courts jurisdiction over any offence which constituted "a violation of the laws and usages of war". ${ }^{5}$ This meant that jurisdiction was narrower in subject matter than Law No. 10 and did not include crimes against peace or crimes against humanity. ${ }^{56}$ Temporally, jurisdiction was limited to crimes committed since 2 September 1939, the day after which Germany invaded Poland, which was narrower than Law No. $10 .{ }^{57}$ Finally, the jurisdiction of British military courts was limited to war crimes "committed either by the Germans or by any person in German employ". Britain was concerned with the prosecution of war crimes against its own and Allied nationals in one and the same war. To be sure, the policy of the British Government as to the punishment of war criminals was considered in 1942 by the War Cabinet, which suggested that each of the Allies should try the cases with which it was

\footnotetext{
50) Ibid.

51) Ibid.

52) War Cabinet, 'Conclusions of a Meeting of the War Cabinet held in the Prime Minister's Room', 4 October 1944, National Archives, cab/65/44/2; War Cabinet, 'War Crimes. Memorandum by the Secretary of State for Foreign Affairs and the Lord Chancellor', 14 November 1944, National Archives, cab/66/57/48.

53) Law Reports, vol. XV, p. 46.

54) Law Reports, vol. XV, p. 30; Rogers, supra note 48, p. 789.

55) Supra note 48, Regulation 1.

56) History, supra note 10 , p. 216.

57) Supra note 48, Regulation 1.
} 
"concerned", including offences committed against its own nationals. ${ }^{58}$ Unsurprisingly, priority was given to the prosecution of war crimes against British nationals; the prosecution of persons in the British zone accused of war crimes against Allied nationals was of a secondary consideration, where such crimes could not be tried by the Allied government "concerned" ${ }^{59}$ It is also notable that the British Government did not recognise the existence of any right of universal jurisdiction under international law; it was even cautious of trying enemy nationals for war crimes against foreign nationals of Allied nations, which explains why the jurisdiction of British military courts was construed in narrow terms. ${ }^{60}$

The jurisdiction of British military courts is reflective of the practice of the other Great Powers in their respective zones of occupied Germany. As with Britain, the Soviet Union did not apply directly Law No. 10. The Soviet Union had refused to join the UNWCC, ${ }^{61}$ which was mandated to "investigate war crimes committed against nationals of the United Nations" ${ }^{2}$ Instead, in order to investigate war crimes committed on Soviet territory by enemy forces during the war, the Soviet Union issued a Decree of 2 November 1942, which established the "Extraordinary State Commission for ascertaining and investigating crimes perpetrated by the Germano-Fascist invaders and their accomplices, and the damage inflicted by them on citizens, collective farms, social organisations, State enterprises and institutions of the USSR" ${ }^{63}$ The Soviet Union prosecuted war crimes under a Decree of the Presidium of the Supreme Soviet of 19 April 1943, which provided courts martial with jurisdiction over "German-Fascist criminals guilty of great crimes against Soviet citizens". ${ }^{64}$ The Decree inter alia did not

58) War Cabinet, 'Treatment of War Criminals', 22 June 1942, National Archives, cab/66/25; see also War Cabinet, 'War Crimes Bill', 2 October 1944, National Archives, cab/55/50.

59) Cabinet decision of November 1944, National Archives, cab 65/44; A. G. Somerhough, Situation Report War Crimes Group, North West Europe to Shapcott, 20 September 1947, National Archives, Foreign Office 371 64718/C13471/7675/180; Shapcott Memorandum to the Secretary of State for War, the Lord Chancellor and the Foreign Office, 15 October 1947, National Archives, Foreign Office 371 64718/C13471/7675/180; Memorandum from Shapcott, 15 October 1947, National Archives, War Office 3212197 0160/2573; Claire L. Sharman, 'War Crimes Trials between Occupation and Integration: The Prosecution of Nazi War Criminals in the British Zone of Germany', (Unpublished D.Phil Thesis, University of Southampton, 2007).

${ }^{60)}$ Cabinet Paper, 'Treatment of War Criminals', May 1944, National Archives, Lord Chancellor's Office $2 / 2976$.

61) War Office Memorandum 1, 7 January 1947, National Archives, War Office 3212197.

62) War Cabinet, 'United Nations War Crimes Commission. Memorandum by the Lord Chancellor', 2 June 1944, National Archives, 66/50/44.

63) George Ginsburgs, 'The Nuremberg trial: Background', in George Ginsburgs and Vladimir N. Kudriavstev (eds.), The Nuremberg Trial and International Law (Martinus Nijhoff, Dordrecht, 1990) p. 16. See also Ilya Bourtman, "Blood for Blood, Death for Death": the Soviet Military Tribunal in Krasnodar, 1943', 22 Holocaust and Genocide Studies (2008); Alexander V. Prusin, "“Fascist Criminals to the Gallows!": The Holocaust and Soviet War Crimes Trials, December 1945-February 1946', 17 Holocaust and Genocide Studies (2003).

64) Ginsburges, ibid., p. 19. 
legally define war crimes and instead used all-encompassing terms of "atrocities" and "evil deeds". ${ }^{65}$ Thus, jurisdiction was limited to crimes by the enemy on occupied Soviet territories and against its nationals.

The jurisdiction of Military Government Tribunals in the French zone was provided for by French Ordinance and applied to "all war crimes defined by international agreements in force between the occupying Powers whenever the authors of such war crimes, committed after the 1st September, 1939, are of enemy nationality or are agents, other than Frenchmen, in the service of the enemy". ${ }^{66}$ Military Government Tribunals were also given jurisdiction to punish all crimes set out in Law No. $10 .{ }^{67}$ However, the jurisdiction of these tribunals was restricted to crimes by persons belonging to the enemy. The United States used Military Government Courts and Military Commissions in its zone of occupied Germany. ${ }^{68}$ Military Commissions had jurisdiction over violations of the laws and customs of war by "enemy combatants and civilians" during military operations in which the United States was engaged. ${ }^{69}$ The jurisdiction of Military Government Courts was also restricted to crimes by the enemy which violated the laws and customs of war, the laws of "Allied Forces" and the laws of occupied territory. ${ }^{70}$ In order to implement the Judgment of the Nuremberg Tribunal, Ordinance No. 7 was passed providing for the establishment in the American zone of Military Tribunals with jurisdiction to "try and punish persons charged with offences recognised as crimes in ... Law No. 10". ${ }^{71}$ However, the jurisdiction of these tribunals was restricted to the punishment of crimes by persons belonging to the enemy. ${ }^{72}$

Law No. 10 and the municipal provisions of the Great Powers did not provide for universal jurisdiction. ${ }^{73}$ The Great Powers, as with the other Allied nations, were concerned first and foremost with the prosecution of war crimes committed by the 'enemy' in their own territories, where they had experienced firsthand enemy occupation, and against their own nationals. It is important to remember

65) Prusin, supra note 63, p. 4.

66) French Ordinance No. 20 of 25 November 1945 of the French Commander-in-Chief, Article 1. For discussion of French Military Government Tribunals in the French zone, see Law Reports, vol. III, Annex II.

67) Ordinance No. 36 of 25 February 1946 of the French Commander-in-Chief, Article 1.

68) For discussion of the jurisdiction of United States Military Government Courts and Military Commissions, see Law Reports, vol. I, Appendix II; Law Reports, vol. III, Appendix III; Law Reports, vol. XV, p. 30.

69) Order of 25 August 1945, paragraph 1a; The Hadamar Trial, Law Reports, vol. I, p. 52.

70) Ordinance No. 2 of the Supreme Commander, Articles 2(1)-(2); see also The Justice Trial, Law Reports, vol. VI.

71) Ordinance No. 7, Article 1.

72) The Justice Trial, Law Reports, vol. VI.

73) See also Report of the Commission on the Use of the Principle of Universal Jurisdiction by some NonAfrican States as Recommended by the Conference of Ministers of Justice/Attorneys General, supra note 7, para. 14 
that, although the Great Powers declared to act "in the interests of the United Nations", ${ }^{74}$ the trial of war criminals would not have occurred had their own nationals and national interests not been threatened or injured. There was even reluctance in some cases to prosecute war crimes which did not involve their own "direct interest". ${ }^{75}$ Where the victims of war crimes in German concentration camps belonged to more than one of the Allies, it was agreed that prosecutions would be undertaken by the Power which occupied the zone in which the camp was situated, and the "representatives of all Allied countries whose nationals were victims would be taken into consultation." " 6 Allied commanders were also instructed to forward evidence collected in their own zones "to the United Nations Government against whose national or nationals the crime was committed". ${ }^{77}$ In this regard, Law No. 10 provided for the exchange of accused war criminals among the four occupied zones and to other Allied nations, so that injured States could undertake their own prosecutions, although each zone had ultimate power to decide whether, and, if so, which, alleged war criminals would be handed over. ${ }^{78}$ This is consistent with the international agreements concluded by the Allies during the war, which provided that accused enemy war criminals would be sent back for trial to the particular injured Allied nation. ${ }^{79}$ As for crimes against humanity, namely, the systematic ill-treatment and extermination by German authorities of their own Jewish nationals, which were vast and unprecedented, the Great Powers had no interest in their prosecution, as they did not involve their own or Allied nationals. ${ }^{80}$ Crucially, jurisdiction over crimes against humanity was interpreted as requiring a war nexus, whereby they had to be committed by the enemy during or in connection with the crime of aggressive war in which the prosecuting State was engaged, or in connection with war crimes

74) Declaration of the Great Powers for the establishment of the Allied Control Council, Law Reports, vol. XV, p. 37; London Agreement, 'United States-France-Great Britain-Soviet Union Agreement for the Prosecution and Punishment of the Major War Criminals of the European Axis' (8 August 1945), 39 American Journal of International Law (1945), Preamble, para. 5.

75) E.g., see Cabinet, 'War Crimes: Case of German Generals in British Custody: Memorandum by the Secretary of State for War', Cabinet Papers (48) 151, 17 June 1948, National Archives, cab/129/28, para. 10; Cabinet, 'War Crimes: Case of German Generals in British Custody: Memorandum by the Attorney-General', Cabinet Papers (48) 159, 22 June 1948; also, War Cabinet, 'War Criminals. Memorandum by the Attorney-General', 18 May 1945, National Archives, cab/66/65/63.

76) War Cabinet, 'War Criminals. Memorandum by the Attorney-General', 18 May 1945, National Archives, cab/66/65/63.

77) War Cabinet, 'War Crimes', 14 November 1944, National Archives, cab/66/57/48.

78) Supra note 41, Article IV.

79) For text of the Moscow Declaration, see History, supra note 10, pp. 107-108; London Agreement, supra note 74, Preamble, para. 3 and Article 4. Anthony Glees, 'The Making of British Policy on War Crimes: History as Politics in the UK', 1 Contemporary European History (1992) p. 180.

80) Priscilla D. Jones, 'British Policy towards German Crimes against German Jews, 1939-1945', 36 Leo Baeck Institute Year Book (1991). 
therein; otherwise, they had to be committed against their own or Allied nationals. ${ }^{81}$ The war nexus will be returned to below. This attitude towards crimes against humanity by German authorities against German nationals was reflected in the UNWCC's mandate, which did not include the investigation of these crimes. ${ }^{82}$ Following the enactment of Law No. 10, Britain and the U.S., in accordance with that law, delegated to German courts the prosecution of crimes against humanity ${ }^{83}$ Law No. 10 would appear to represent an agreement between the Great Powers, which was adhered to by the other Allies, for the punishment of a 'common enemy'.

\section{The Punishment of Crimes under International Law by a 'Common Enemy'}

A crucial fact indicating that the Allies did not exercise universal jurisdiction over war crimes, or crimes against peace and crimes against humanity, is that the accused were either "enemy nationals", being of German or Japanese nationality, or otherwise persons of any other nationality, including nationals of neutral countries, who could be treated as either "serving", "belonging", "associating", "identifying" or "assimilating" themselves with the "enemy" ${ }^{84}$ This represents, it is submitted, the punishment by the Allies of crimes under international law by a "common enemy" ${ }^{85}$ This is supported by numerous official proclamations made during the war. The term "Allies" was solidified by the Declaration by the United Nations in 1942, which required nations to cooperate in fighting a common

81) The Hadamar Trial, Law Reports, vol. I, p. 53; The Belsen Trial, Law Reports, vol. II; The Flick Trial, Law Reports, vol. IX, pp. 25-26, 44; The Justice Trial, Law Reports, vol. VI; U.S. v. Ernst Von Weizsaecker et al. (Case XI), 20 December 1947-14 April 1949; In re Ohlendorf and Others, 15 ILR 656; Prusin, supra note 63, p. 6; Henry Friedlander, 'The Deportation of the German Jews PostWar German Trials of the Nazi Criminals', 29 Leo Baeck Institute Year Book (1984) p. 202; Arieh J. Kochavi, 'The Response to Nazi Germany's Crimes Against Axis Nationals: The American and British Positions', 5 Diplomacy and Statecraft (1994).

82) War Cabinet, 'United Nations War Crimes Commission. Memorandum by the Lord Chancellor', 2 June 1944, National Archives, 66/50/44.

83) Supra note 41, Article III. See also History, supra note 10, pp. 214, 466; Egon Schwelb, 'Crimes Against Humanity', 23 British Yearbook of International Law (1946) p. 219; Friedlander, supra note 81 .

84) See The Hadamar Trial, Law Reports, vol. I, p. 54; The Belsen Trial, Law Reports, vol. II, p. 150; The Dachau Concentration Camp Trial, Law Reports, vol. XI, p. 9; Trial of Susuki Motosuke, Law Reports, vol. XIII, pp. 127-129; Trial of Gustav Alfred Jepson, Law Reports, vol. XV, p. 46; Trial of Joaquin Espinosa, Law Reports, vol. XV, p. 46; In re Rohrig, Brunner and Heinze, 17 ILR 397; Richard R. Baxter, 'The Municipal and International Law Basis of Jurisdiction over War Crimes', 28 British Yearbook of International Law (1951) p. 391.

85) The term "common enemy" was adopted by the UNWCC in its reports on a number of war crimes trials, including The Almelo Trial, Law Reports, vol. I, p. 42; The Hadamar Trial, Law Reports, vol. I, p. 53; The Zyklon B Case, Law Reports, vol. I, p. 103. 
enemy with whom they were at war. ${ }^{86}$ The "Moscow Declaration on German Atrocities" of 30 October 1943 declared jointly for the first time by the Great Powers, and was adhered to by the other Allies, the punishment of crimes committed during the war by those "German officers and men and members of the Nazi Party" and "Hitlerite forces". ${ }^{87}$ The London Agreement, signed by the Great Powers, was entitled "the Prosecution and Punishment of the Major War Criminals of the European Axis". ${ }^{88}$ Article 1 of the Charter of the International Military Tribunal at Nuremberg, annexed to London Agreement, provided for the "just and prompt trial and punishment of the major war criminals of the European Axis." The preambular paragraph to Article 6 of the Charter inter alia, which defined the jurisdiction of the Nuremberg Tribunal ratione materiae as crimes against peace, war crimes and crimes against humanity, began by stating that the accused must have been "acting in the interests of the European Axis countries". ${ }^{89}$ This suggests that the Allies were concerned with the punishment of crimes under international law committed by a common enemy and as part of a State policy of aggressive war, in which they were engaged. ${ }^{90}$ The same may be said of the punishment of war criminals in the Far East. ${ }^{91}$ The International Military Tribunal at Tokyo was established by the Allies for the "trial and punishment of the major war criminals in the Far East". ${ }^{92}$ More specifically, it had jurisdiction to try and punish Japanese and other enemy "Far Eastern war criminals" for war crimes and crimes against humanity, where such persons were also "charged with offences which include Crimes Against Peace". ${ }^{93}$ In other words, Allies were concerned with punishing crimes by a common enemy, which were

86) See Dan Pelch, 'How the United Nations beat Hitler and Prepared the Peace', 22 Global Society (2008).

87) Moscow Declaration, supra note 79; see also 'Punishment for War Crimes: The Inter-Allied Declaration of St. James Palace, London, 13 January 1942', ibid., p. 89.

88) London Agreement, supra note 74.

89) Ibid.

90) See William A. Schabas, 'State Policy As An Element of International Crimes', 98 Journal of International Criminal Law and Criminology (2008); Guyora Binder, 'Representing Nazism: Advocacy and Identity at the Trial of Klaus Barbie', 98 The Yale Journal (1989) p. 1334.

91) See Cairo Declaration of 1 December 1943, 38 American Journal of International Law (Spec. Supp.) (1944) p. 11; Postdam Declaration (26 July 1945) and the Japanese Instrument of Surrender (2 September 1945), in Neil Boister and Robert Cryer (eds.), Documents on the Tokyo International Military Tribunal. Charter, Indictments and Judgments (Oxford University Press, Oxford, 2008) p. 3; see also, Judgment of the International Military Tribunal for the Far East, in Boister and Cryer, ibid.; per Dissenting Opinion of the Member from France, ibid., p. 665; Dissenting Opinion of Mr. Justice Röling, ibid., pp. 682-683; Judgment of the Honourable Mr. Justice Pal, ibid., p. 819.

92) Charter of the International Military Tribunal for the Far East (26 April 1946), Article 1, in Boister and Cryer, ibid., p. 7.

93) Ibid., Article 5; see also, Special Proclamation-Establishment of an International Military Tribunal for the Far East (19 January 1946), Article 1, in Boister and Cryer, ibid., p. 5. 
part of a State policy of aggressive wars against one or more of the eleven Allied nations which established the Tribunal. ${ }^{94}$

This was reflected in the enactment by the Allies of national laws at the end of the war, conferring upon their own domestic courts extraterritorial jurisdiction over crimes under international law. ${ }^{95}$ There is a notable alignment in these national laws providing for jurisdiction over international crimes committed by persons belonging to a common enemy; this created an important jurisdictional nexus with the States prosecuting these crimes. Jurisdiction was also limited to crimes during war in which these States were engaged, which provided an important temporal nexus. It should also be noted that these national laws provided for a nexus to the national interests of the prosecuting State, such as crimes against their own or Allied nationals. ${ }^{96}$ In that connection, the concept of 'Allied' nationality was expanded so that inhabitants of former enemy occupied countries could be "treated" as Allied nationals. ${ }^{97}$ This meant that once enemy occupied countries had capitulated and accepted armistice with the Allies, the nationals of these countries could be treated as 'Allied' and jurisdiction could be exercised over war crimes which had been committed against them by the enemy. ${ }^{98}$ It is within this

94) Solis Horwitz, 'The Tokyo Trial', 28 International Conciliation (1950) p. 487.

95) See Australian War Crimes Act of 1945, Law Reports, vol. V; Austrian War Criminals Act of 1945 (Kriegsverbrechergesetz); Belgian Decree of 1943 and the Belgian Law of 1947, Law Reports, vol. XV, Annex I; Canadian War Crimes Regulations of 1945, re-enacted in the Act Respecting War Crimes of 1946, Regulation 2, Law Reports, vol. IV, Annex I; Chinese Law Governing the Trial of War Criminals of 1946, Law Reports, vol. XIV, Annex I, Czechoslovakian Retribution Decree No. 16 of 1945, as amended by Law No. 22 of 1946, Law Reports, vol. XV, Annex I; Danish Punishment of War Crimes Act of 1946, Law Reports, vol. XV, pp. 32-33; Netherlands Extraordinary Penal Law Decree of 1943, Article 4, as amended by Act of 19 July 1947, Article 27A, Law Reports, vol. XI, p. 97; In re Rohrig et al., supra note 84; French Ordinance of 1944, Law Reports, vol. III, Appendix II; Netherlands East Indies Decree No. 44 of 1946, Law Reports, vol. VI, p. 93; The Norwegian Law on the Punishment of Foreign War Criminals of 1946, Law Reports, vol. I, pp. 31, 44; Law Reports, vol. III, p. 83; Law Reports, vol. XV, pp. 30-31; Polish Decree concerning the punishment of Fascist-Hitlerite criminals guilty of murder and ill-treatment of the civilian population and of prisoners of war, and the punishment of traitors of the Polish nation of 1944, and the Polish Proclamation of 1947, Law Reports, vol. VII, Annex I, Slovakian Decree No. 33/1945 as amended by Decree Nos. 83/1945 and 57/1946; Yugoslav Law on War Crimes and Treasonable Activities of 1945, Law Reports, vol. XV, pp. 207-209. See also History, supra note 10, pp. 468-475; Axel Marschik, 'The Politics of Prosecution: European Nationals Approaches to War Crimes', in McCormack and Simpson, supra note 1, Chap. 3.

96) See also Jean S. Pictet (ed.), Commentary. I Geneva Convention for the Amelioration of the Condition of the Wounded and Sick in Armed Forces in the Field (ICRC, Geneva, 1952) p. 353.

97) Trial of Susuki Motosuke, Law Reports, vol. XIII, p. 129; also, History, supra note 10, pp. 172-173.

98) See The Justice Trial, Law Reports, vol. VI, p. 79; The Trial of Albert Kesserling, Law Reports, vol. VIII; The Dachau Concentration Camp Trial, Law Reports, vol. XI, p. 10; Trial of Susuki Motosuke, ibid., vol. XIII, p. 127; Law Reports, vol. XV, pp. 43, 135; Moscow Declaration, supra note 79; Law No. 10, supra note 41, Article 2(1)(b); Nuremberg Charter, supra note 74, Article 6(b). See also Baxter, supra note 84; G. Brand, 'The War Crimes Trials and the Laws of War', 26 British Yearbook of International Law (1949) p. 416. 
context that the Almelo Trial, which has already been discussed above, must be understood. It is useful at this point to refer to Lord Wright, whose conclusion as to the basis of jurisdiction over war crimes, after examining State practice, is revealing:

Under the doctrine of the Universality of jurisdiction over war crimes, international law takes account of the crime itself rather than (a) the nationality of the victim (provided that he can be regarded as an Allied national or treated as such), or (b) the nationality of the accused (provided that he can be regarded as having with the enemy), or (c) the place of the offence.99

It is clear that, despite Lord Wright's nomenclature, this is not really universal jurisdiction at all; and this is the problem with Lord Wright's reliance upon the article by Cowles, instead of examining actual State practice. The result is a fundamental mismatch between Lord Wright's pretensions of universal jurisdiction, on the one hand, and the partialities and discriminations of jurisdiction in State practice, on the other. This means that universal jurisdiction over war crimes has no foundation in State practice in the aftermath of World War II. ${ }^{100}$ Crucial to jurisdiction over war crimes was the status of the accused, as belonging to the 'enemy', and of victims, as belonging to the 'Allies'. Judge Baxter has rightly observed that jurisdiction "falls considerably short" of being universal where it is exercised by a belligerent over persons associated with its enemies for crimes committed against either its own or Allied nationals. ${ }^{101}$ Rather, as will be discussed below, it suggests that jurisdiction was based on the protective principle. ${ }^{102}$

A more difficult issue faced by the Allies was the prosecution of crimes against humanity committed by German authorities against German Jews on German territory, which did not constitute war crimes under international law; this meant that the victims of these crimes could not be treated, for the purpose of jurisdiction, as Allied nationals. ${ }^{103}$ However, the Allies did not exercise universal jurisdiction over these crimes either. The Nuremberg Charter provided that crimes against humanity had to be committed in the "interests of the European Axis countries" and, moreover, "in execution of or in connection with any crime within the jurisdiction of the Tribunal", namely crimes against peace or war crimes. ${ }^{104}$ This was affirmed by the Judgment of the Nuremberg

\footnotetext{
99) Law Reports, vol. XV, p. 43 (brackets original but emphasis added).

100) See also Arrest Warrant, supra note 3, per Joint Separate Opinion of Judges Higgins et al., pp. 70-71.

101) Baxter, supra note 84, pp. 391-392.

102) See also, Vanni E. Treves, 'Jurisdictional Aspects of the Eichmann Case', 47 Minnesota Law Review (1962-1963) p. 575; Baxter, ibid., p. 383.

103) War Cabinet, 'United Nations War Crimes Commission. Memorandum by the Lord Chancellor', 2 June 1944, National Archives, 66/50/44; The Justice Trial, Law Reports, vol. VI, pp. 40, 79; Law Reports, vol. XV, p. 135. See also History, supra note 10, pp. 174-177.

104) Supra note 86, Article 6, Preamble \& Article 2 (c).
} 
Tribunal. ${ }^{105}$ The Tokyo Charter expressly stated that crimes against humanity had to be committed in connection with crimes against peace to fall within the Tribunal's jurisdiction, although the Allies had no interest in prosecuting these crimes in the Far East. In this way, crimes against humanity were interpreted as having a war nexus; they were carefully linked with crimes against peace and war crimes which, in turn, had the effect of restricting the scope of jurisdiction inter alia to the punishment of a common enemy involved in a State policy of aggressive war, in which the prosecuting States were engaged. ${ }^{106}$ The reasons for imposing this nexus appear to be that the Allies had no interest in the prosecution of crimes against humanity beyond or unconnected to the immediate wars in which they were engaged. Secondly, by restricting jurisdiction, the Allies sought to protect, rather than to override, State sovereignty. ${ }^{107}$ Lastly, it ensured that the States prosecuting crimes against humanity had themselves been injured by the aggressive wars of a common enemy, thus providing what was regarded as a sufficient jurisdictional nexus over these crimes under international law. ${ }^{108}$ The protective principle would thus appear to have provided the basis of jurisdiction over these crimes. ${ }^{109}$

The State practice at the end of the World War II is illustrative of a trend to provide for the trial and punishment of foreign nationals for crimes under international law. Jurisdiction was, however, restricted to persons belonging to a common enemy over crimes that were part of a State policy of aggressive war, in which the prosecuting States were engaged and had been injured. This suggests that the right under international law to punish international crimes was regarded as belonging to the injured State.

\section{The Right under International Law of the 'Injured' State to Punish Crimes under International Law}

The right to try and punish persons for violating the laws of war has long been accepted as a principle under international law and in customary practice to belong to a belligerent over its enemy, wherever such individuals should fall into

\footnotetext{
105) International Military Tribunal (Nuremberg), 'Judgment and Sentences', 41 American Journal of International Law (1947) p. 249.

106) See Schabas, supra note 90, p. 961.

107) See Beth Van Schaak, 'The Definition of Crimes Against Humanity: Resolving the Incoherence',

37 Columbian Journal of Transnational Law (1998-1999) p. 791.

108) See Memorandum Submitted by the Secretary-General, supra note 14, pp. 70-72; also, Indictment of the Nuremberg Tribunal, Counts I \& IV, Nuremberg Trial Proceedings, vol. I, supra note 38; Ginsburgs, supra note 63, p. 35.

109) See also Carnegie, supra note 21, p. 410.
} 
its power. ${ }^{110}$ This right of jurisdiction over war crimes, it has been argued, is based on the principle of universality and derives from "the bare fact that the person charged is within the custody of the Court; his nationality, the place where the offence was committed, the nationality of the victims are not generally material". ${ }^{111}$ However, this is misleading; crucially, the State which has "custody" over the accused is not any State whatever, but, rather, the belligerent, or one of its Allies, which has been "injured" or "offended" by the violation of the law of war. ${ }^{12}$

The right of the injured State to punish war crimes was recognised in the mid-nineteenth century by Moynier, the President of the International Committee of the Red Cross (hereafter ICRC), in his defence of a proposed reform of the 1864 Geneva Convention to fix uniformly criminal punishments for breaches of its provisions. According to Moynier, under international law and existing State practice, it is possible the offender will be punished under the municipal law of his own State; "[o]n the other hand, he may be captured by the enemy who has been the victim of his offence, and being then subject to the jurisdiction of the enemy's courts and liable to the penalties which the enemy's laws imposes". ${ }^{113}$ Similarly, after World War I, it was suggested by the 'British Committee of Enquiry into Breaches of the Laws of War' that, for centuries, individual offenders of the laws and usages of war, though uncodified, unclear and far from

110) Edward W. Hall, A Treatise on International Law (Clarendon Press, Oxford, 1890) p. 495; History, supra note 10, p. 29. See also the Report presented to the Preliminary Peace Conference on 29 March 1919, 'Commission on the Responsibility of the Authors of the War and on Enforcement of Penalties'. 14 American Journal of International Law (1920) p. 121, and the Memorandum of American Commissioners concurring on this point, ibid., p. 141; Law Reports, vol. XV, p. 26; Judgment of the International Military Tribunal for the Far East, supra note 91, p. 79; per Separate Opinion of the President, Sir William Flood Webb, ibid., p. 632; per Concurring Opinion by the Honourable Mr. Justice Delfin Jaranilla, ibid., p. 649; per Judgement of the Honourable Mr. Justice Pal, ibid., pp. 830, 833; Hans Lauterpacht, 'The Law of Nations and the Punishment of War Crimes', 21 British Yearbook of International Law (1944) pp. 61-62; Yoram Dinstein, The Conduct of Hostilities under the Law of International Armed Conflict (Cambridge University Press, Cambridge, 2004) p. 228.

111) Lord Wright, Law Reports, vol. XV, p. x; History, supra note 10, p. 549. See also the recent study by the ICRC, Jean-Marie Henckaerts and Louise Doswald-Beck (eds.), Customary International Humanitarian Law (Cambridge University Press, Cambridge, 2005) pp. 605-606.

112) 'First, Second and Third Interim Reports from the Committee of Enquiry into Breaches of the Laws of War', supra note 29, para. 23; Bellot, supra note 29, pp. 43, 52; George Manner, 'The Legal Nature and Punishment of Criminal Acts of Violence Contrary to the Laws of War', 37 American Journal of International Law (1943) p. 434; Quincy Wright, 'The Law of Nuremberg Trial', 41 American Journal of International Law (1947) pp. 46, 49; Gerald I. A. Draper, 'The Modern Pattern of War Criminality', in Yoram Dinstein and Mala Tabory (eds.), War Crimes in International Law (Martinus Nijhoff, London, 1996) p. 155; Judgment of the International Military Tribunal for the Far East, supra note 91, per Concurring Opinion of the Honourable Mr. Justice Delfin Jaranilla, p. 650; per Judgment of the Honourable Mr. Justice Pal, ibid., pp. 818-820; In re Rohrig et al., supra note 84 .

113) Cited in Pictet, supra note 96, pp. 353-354. 
complete, "have been tried and punished by the Military Courts of the offended State, whenever they have come within its jurisdiction or power." ${ }^{114}$ Thus, under international law, the right to exercise jurisdiction for the trial and punishment of war crimes has traditionally been regarded as pertaining to the injured State, while the separate issue of obtaining custody of the accused, on the other hand, was relevant, as a matter of practicality, to its enforcement. The problem of obtaining custody of enemy personnel, which has traditionally depended upon the total defeat of the enemy, has meant that actual prosecutions of war crimes have been rare and difficult. ${ }^{115}$ For this very reason, the Allies during World War II issued an ultimatum, prior to the atomic bombing of Hiroshima, demanding the Japanese Government "unconditionally surrender" all Japanese armed forces and leaders so that "stern justice shall be meted out to all war criminals", otherwise Japan would suffer "prompt and utter destruction". ${ }^{116}$ Similarly, the Allies imposed upon Germany, which was said to arise from its "complete defeat and utter surrender", the duty to surrender for trial all persons as requested by the Allies, including its leaders. ${ }^{17}$

The very notion that, under international law, the injured belligerent has the right to punish individuals belonging to its enemy postulates that jurisdiction is grounded in the recognition by international law of the right of the State to protect its sovereignty and security and certain other of its vital interests. This apparent principle of protective jurisdiction is by no means novel and, indeed, has its roots in the early treatises on international law. It should be noted that, in these classical writings, the infliction by a sovereign of punishment over his enemy was itself one of the aims of waging a 'just' war; of course, no sovereign has ever conceded the waging of war to be unjust. This also suggests that the protective principle was bound with a broader right of war. Fransciso de Vitoria wrote in the early sixteenth century on the law of war and, in particular, "What and how extensive measures may be taken in a just war against the enemy". Vitoria asserted that the sovereign has a right under the law of nations to wage war in order to

\footnotetext{
114) Ibid.

115) Trial of General Tomoynki Yamashita Case, Law Reports, vol. IV, p. 42. Theodore Meron, 'The Case for War Crimes Trials in Yugoslavia, 72 Foreign Affairs (1993) p. 123; Theodore Meron, 'Reflections on the Prosecution of War Crimes by International Tribunals', 100 American Journal of International Law (2006) p. 554; Ernst J. Cohn, 'The Problem of War Crimes Today', 26 Problems of Peace and War (1940) p. 129; 'First, Second and Third Interim Reports from the Committee of Enquiry into Breaches of the Laws of War, with Appendices', supra note 29, para. 25.

116) Postdam Declaration (Proclamation Defining Terms for Japanese Surrender, 26 July 1945), paras. 10, 13, in Boister and Cryer, supra note 91, p. 1; Japanese Instrument of Surrender (2 September 1945), ibid., p. 3.

117) Agreement Between the Governments of the United Kingdom, the United States of America, and the Union of Soviet Socialist Republics, and the Provisional Government of the French Republic on Certain Additional Requirements to be Imposed on Germany (20 September 1945), section 10; Judgment of the Nuremberg Tribunal, supra note 105, p. 216.
} 
"avenge the injury done by the enemy and to teach the enemy a lesson by punishing them for the damage they have done". ${ }^{118}$ Vitoria was under no doubt that "princes can punish enemies who have done a wrong to their State and that after a war has been duly and justly undertaken the enemy are just as much within the jurisdiction of the prince who undertakes it as if he were their proper judge." 119 The justification for punishing the enemy was, according to Vitoria, to secure the future peace, tranquillity and security of the nation - "the end and aim of war" which cannot be had unless the enemy is deterred and "restrained by fear of punishment." ${ }^{220}$ This right of jurisdiction over the enemy was, according to Vitoria, "granted by the law of nations". ${ }^{121}$ Thus, Vitoria considered the punishment of the enemy, as one of the aims of war, to be justifiable to effectuate retribution for past injuries and to deter future harm. Writing on the law of nations in the following century, Grotius posed the question: "What causes of war may be called justifiable?" 22 Grotius asserted that "No other just cause for undertaking war can there be excepting injury received." 123 Grotius further argued that war may be waged for the infliction of punishment. ${ }^{124}$ Writing on the law of nations in the mid-eighteenth century, Vattel asserted that "the just and lawful object of every war [is] to avenge or prevent injury". ${ }^{125}$ For Vattel, the right " $[\mathrm{t}] \mathrm{o}$ avenge signifies here to prosecute the reparation of an injury ... and also punish the offender ... with a view to providing for our future safety. The right to security authorises us to do all this." 126 An important principle of international law, since its modern development, is that a sovereign may punish its enemy for past injuries and to protect the future security of the State.

In the early twentieth century, Oppenheim, who co-authored the British Manual of Military Law of 1914, asserted that "[w]ar crimes are hostile acts of soldiers or other individuals as may be punished by the enemy on capture of the

\footnotetext{
118) Anthony Pagden and Jeremy Lawrence (eds.), Vitoria, Political Writings (Cambridge University Press, Cambridge, 1991) pp. 300-304; James B. Scott, The Catholic Conception of International Law: Francisco de Vitoria, Founder of the Modern Law of Nations, Francisco Suarez, Founder of the Modern Philosophy of Law in General and in Particular of the Law of Nations (Georgetown University Press, Washington, 1934); Gregory M. Reichberg, 'Preventative War in Classical Just War Theory', 9 Journal of the History of International Law (2007) pp. 13-14.

119) Scott, ibid., pp. 43, 53.

120) Ibid., pp. 43-44, 53, 55.

121) Ibid., p. 42.

122) Hugo Grotius, De Jure Belli Ac Pacis (Classics in International Law Series, James B. Scott (ed.), 1925), BK II.

123) Ibid., Chap I, para. 1.4.

124) Ibid., Chap. I, para. 2.2.

125) Emerich de Vattel, The Law of Nations, Or, Principles of the Law of Nature, Applied to the Conduct and Affairs of Nations and Sovereigns, with Three Early Essays on the Origin and Nature of Natural Law and on Luxury (Bela Kapossy and Richard Whitmore (eds.), Indianapolis, Liberty Fund, 2008), BK III, Chap. III.

126) Ibid.
} 
offenders." 127 According to Oppenheim, "[e]very belligerent may, and actually must, in the interest in his own safety punish these acts". ${ }^{128}$ The protective principle was recognised as the basis of jurisdiction over war crimes at the end of World War I. The Allies, each of whom had been injured by numerous violations of the laws and customs of war by Germany, agreed to set up an Inter-Allied Commission of Fifteen Members (Commission), which was instructed inter alia to report upon "the facts as to breaches of the laws and customs of war committed by the forces of the German Empire and their Allies, on land, on sea, and in the air during the present war". ${ }^{129}$ It goes without saying that each of the Allies was concerned with the punishment of persons belonging to a common enemy for breaches of the laws and customs of war against their own nationals. ${ }^{130}$ The majority of the Commission reported that "[a]ll persons belonging to enemy countries ... who have been guilty of offences against the laws and customs of war or the laws of humanity, are liable to criminal prosecution". ${ }^{131}$ It went on to conclude that:

Every belligerent has, according to international law, the power and authority to try the individuals alleged to be guilty of [violations of the laws and customs of war], if such persons have been taken prisoner or have otherwise fallen into its power. Each belligerent has, or has the power to set up pursuant to its own legislation, an appropriate tribunal, military or civil, for the trial of such cases. ${ }^{132}$

It was thus recognised by the Commission the right under international law of each of the injured Allies to put on trial in municipal tribunals, upon capture, persons belonging to the enemy for violation of the laws and customs of war. The United States representatives, while dissenting from the majority of the Commission as regards the right to prosecute breaches of the laws of humanity, concurred with the majority that a State possesses jurisdiction over war crimes by its enemies, regardless of where such crimes are committed, "when the person or property injured by the offence is of the same nationality as the military tribunal". ${ }^{133}$ This was given formal sanction by the Treaty of Versailles, which required Germany to hand over to each of the injured Allies for the trial its nationals accused of violating the laws and customs of war. ${ }^{134}$ Although Germany

127) Lassa Oppenheim, International Law: A Treatise, vol. II, War and Neutrality, (Longmans, London, 1912) p. 309, para. 251 (italics added).

128) Ibid., p. 310.

129) 'Commission on the Responsibility of the Authors of the War and on Enforcement of Penalties', supra note 110, p. 95.

130) See 'First, Second and Third Interim Reports from the Committee of Enquiry into Breaches of the Laws of War, with Appendices', supra note 29.

131) Supra note 129, p. 101 (italics added).

132) Ibid., p. 121.

133) Ibid., pp. 141, 146-147.

134) The Treaty of Versailles, 28th June, 1919, Articles 228-229. 
ultimately refused to do so, it nevertheless recognised in principle the right of the injured State to punish war crimes by its decision, following demands by some of the injured Allies, to put on trial a handful of its nationals. ${ }^{135}$ Thus, at the end of World War I, the right under international law to exercise jurisdiction over enemy war criminals was regarded as belonging, in addition to the adversary, to the injured belligerent.

\section{The Use of the Protective Principle at the End of World War II}

The war crimes trials reported by the UNWCC at the end of World War II are important evidence of State practice. Although there is generally little discussion in these reports as to the right under international law to punish enemy war criminals, some of the most authoritative cases suggest that it was based on the protective principle of jurisdiction.

In The Justice Trial, which involved war crimes and crimes against humanity, a U.S. Military Tribunal sitting in Nuremberg, pursuant to Law No. 10, referred to the universal application of the law of war but placed great emphasis in the ensuing text, as to the right to punish its violations, on the "injured belligerent government". Thus, the tribunal held that:

As to the punishment of persons guilty of violating the law and customs of war, it has always been recognised that tribunals may be established and punishment imposed by the state into whose hands the perpetrators fall. Those rules of international law were recognised as paramount, and jurisdiction to enforce them by the injured belligerent government, whether within the territorial boundaries of the State or in occupied territory, has been unquestioned. ${ }^{136}$

The tribunal inter alia qualified the "state into whose hands the perpetrators fall" by reference to the rights of the "injured belligerent", which suggests that jurisdiction was based on the protective principle. In this regard, it made a crucial distinction, "in connection with the cherished doctrines of national sovereignty", between the "rules of common international law which are universal and superior authority on the one hand, and the provisions for enforcement of those rules which are by no means universal on the other." ${ }^{137}$ While the law of war is of 'universal' application and of "superior authority" to domestic law, the right to punish its violations is restricted by the tribunal to the "injured belligerent", which, asserted the tribunal, is "paramount" and "unquestioned". The tribunal went on

135) See The Llandovery Castle, Germany, Reichsgericht, 16 July 1921; 2 ILR 436; The Dover Castle, Germany, Reichsgericht, 4 June 1921; 2 ILR 429.

136) Law Reports, vol. VI, p. 37; see also In re Oblendorf, 15 ILR 656.

137) Ibid. 
to assert the right of the "offended" State to punish war criminals, "if it can secure jurisdiction over the person". ${ }^{138}$

The most senior court in the Netherlands, the Special Court of Cassation, In re Rohrig, Brunner and Heinze, which involved the deportation of a large number of citizens of occupied Holland, stated that the law of nations "empowers a belligerent State to have enemy war criminals who have offended against its legal interests tried by the judicial organs designated by it on the basis of internationally accepted laws and customs of war." ${ }^{139}$ The court inter alia held that territoriality is not the only relevant principle of jurisdiction over war crimes committed by the enemy against Dutch nationals and, accordingly, in exceptional cases, the extension of the Netherlands criminal law to the conduct of foreign enemy war criminals abroad was in accordance with international law under the principle of "protection of national interests" ${ }^{140}$ The right of the injured State to try enemy nationals for war crimes and crimes against humanity against under the protective principle was also the conclusion of the Netherlands Special Court of Cassation in the Gerbsch case. ${ }^{141}$ That case concerned the prosecution of a German defendant for "serious ill-treatment of Netherlanders" in a punishment camp in Germany, where deported Dutch and Allied nationals had been concentrated. At first instance, the Netherlands Special Criminal Court rejected the argument that it lacked jurisdiction over a German national for war crimes committed in German territory, on the basis that Dutch municipal law conferred upon Dutch courts' jurisdiction over war crimes and crimes against humanity where these were committed against "Dutch subjects or Netherlands interests outside Dutch territory". Thus, the defendant was found guilty of a crime "against Netherlanders and against persons through whom the interest of the Netherlands was or could be harmed." 142 Notably, this latter sentence suggests the existence of a broader right of protective jurisdiction over crimes committed against the nationals of other Allies, "whom the interest of the Netherlands was or could be harmed". The decision of the Special Criminal Court was affirmed by the Netherlands Special Court of Cassation. While the jurisdiction of the court in the Gerbsch case was clearly based on the protective principle, the report of this case, prepared by the UNWCC, stated that "the Court invoked the principle of the so-called "passive nationality"”. ${ }^{143}$ However, the UNWCC, in finding this conclusion, seems to have confused the passive personality and protective

138) Ibid., p. 38.

139) 17 ILR 397, citing In re Ablbrecht, p. 397.

140) Ibid.

141) Law Reports, vol. XIII, p. 131.

142) Ibid., p. 132.

143) Ibid., p. 133. The passive personality principle was also reported in the International Law Reports; see 16 ILR In re Gerbsch 399. 
principles, and gave insufficient consideration to the Netherlands as the injured State. ${ }^{144}$

In The Peleus Trial, a British military court sitting in the British zone of occupied Germany, pursuant to Law No. 10, stated that its jurisdiction over the defendants for war crimes was based on the Royal Warrant and that, as far as international law was concerned, the victims involved British nationals. Interestingly, the report on this case by the UNWCC suggested that, given the British nationality of the victims on board The Peleus, it was unnecessary for the court to have recourse to the fact that Allied nationals were also among the victims and "to the still more general question of the universality of jurisdiction over war crimes." ${ }^{145}$ However, there is no evidence contained within the reasoning of the court to suggest that it was even aware that universal jurisdiction existed; moreover, the court regarded its jurisdiction to be based on the ground that Britain was the "injured" belligerent. ${ }^{146}$

There are many other reported cases which support jurisdiction under the protective principle, as do the trials before the International Military Tribunals at Nuremberg and Tokyo. ${ }^{147}$ The jurisdiction of these latter Tribunals was defined by the terms of their charters and, as has already been discussed above, was limited to the prosecution of crimes by a common enemy. The jurisdiction of the Tokyo Tribunal was also based on the Postdam Declaration and the Special Proclamation, both of which spelled out more clearly as the intention of the Allies the punishment of Japanese war criminals, "including those who have visited cruelties upon our prisoners". ${ }^{148}$ The right to try Japanese war criminals was expressly restricted to any of the nations "with which Japan has been at war". ${ }^{149}$ It has to be borne in mind that the States which had convened the Nuremberg and Tokyo Tribunals and sought the punishment of enemy war criminals were those that had been threatened or injured by aggressive wars and for war crimes against their own nationals, as is made clear from the indictments against the defendants and the Tribunals' Judgments. In the words of Justice Robert Jackson, the Chief Prosecutor at Nuremberg in his opening statement for the prosecution, the tribunal had been convened by "four great nations, flushed with victory and stung

\footnotetext{
144) See Bert V. A. Röling, 'Supra-National Criminal Law in Theory and Practice', in F. H. Van Panhuys et al., (eds.), International Law in the Netherlands, vol. II (Sijthoff \& Noordhoff, the Netherlands, 1979) p. 174; see also In re Friedman, 14 ILR 127.

145) Law Reports, vol. I. p. 13.

146) Ibid., p. 12.

147) The Dostler Case, Law Reports, vol. I, p. 24; The Scuttled U-Boats Case, Law Reports, vol. I, p. 55; The Abbaye Ardenne Case, vol. IV, p. 97; Trial of Lieutenant General Shigeru Sawada et al., Law Reports, vol. V, p. 9; Ex Parte Quirin and Others 317 U.S. 1, p. 26; see also the Memorandum Submitted by the Secretary-General, supra note 14, p. 80 .

148) Postdam Declaration, Article 10, supra note 116; Special Proclamation-Establishment of an International Military Tribunal for the Far East, paras. 2, 7, supra note 93.

149) Special Proclamation, Article 3, ibid.
} 
with injury". ${ }^{150}$ Germany and Japan also both agreed to the surrender for punishment by the injured Allies their leaders and armed forces. It is implicit therefore that jurisdiction was based on the protective principle.

It is important to understand that very few of tribunals defended their right under international law to exercise jurisdiction over enemy war criminals. ${ }^{151}$ This means that jurisdiction has to be inferred from the facts of each case. However, the trials discussed above provide persuasive evidence of State practice that jurisdiction was based on the protective principle. Each of the injured Allies sought to obtain custody of enemy war criminals for crimes against their own nationals or national interests; the nationality of the accused or the victim, or the place where the offence was committed, were regarded as irrelevant. ${ }^{152}$ This is also supported by international agreements concluded by the Allies during the war, including the Moscow Declaration and the St. James Declaration. ${ }^{153}$ It is these agreements which provided the backdrop for the enactment by the Allies of municipal laws at the end of the war, which provided for jurisdiction under the protective principle. The American and British military manuals, which were also used by the armed forces of many other nations, provide further important evidence of State practice and opinio juris in support of jurisdiction over war crimes under the protective principle. ${ }^{154}$

The validity of the protective principle was recognised before World War II over crimes during war and in time of peace, ${ }^{155}$ and specifically over war crimes. ${ }^{156}$

\footnotetext{
150) Justice Jackson's Opening Statement for the Prosecution at Nuremberg, 21 November 1945, supra note 38.

151) See also Carnegie, supra note 21, p. 416.

152) See also Effie, G. H. Pedaliu, 'Britain and the Hand-Over' of Italian War Criminals to Yugoslavia, 1945-48', 39 Journal of Contemporary History (2004); Sandra Wilson, 'After the Trials: Class B and C Japanese War Criminals and the Post-War World', 31 Japanese Studies (2011); Dean Aszkielowicz, 'Repatriation and the Limits of Resolve: Japanese War Criminals in Australian Custody', 31 Japanese Studies (2011) pp. 212-216; Hayashi Hirofumi, 'British War Crimes Trials of Japanese', 31 NaturePeople-Society; Science and the Humanities (2001).

153) See Public Prosecutor v. Klinge, 13 ILR 263, pp. 263-264.

154) American Basic Field Manual, Rules of Land Warfare; British Manual on Military Law, cited in The Dostler Case, Law Reports, vol. I, pp. 23-24; also, Law Reports, ibid., vol. XV, p. 22.

155) Re Urios, 1919-22 Annual Digest 107 (No. 70) (Cour de Cassation, France, 1920); also Wechsler, Counseil de Guerre de Paris, 20 July 1917; Re Bayot, 1923-4 Annual Digest 109 (No. 54) (Cour de Cassation, France, 1923). See also John B. Moore, Report on Extraterritorial Crime and the Cutting Case (United States Department of State, Washington, 1887); James B. Scott, 'The Two Institutes of International Law', 26 American Journal of International Law (1932) p. 89; Brierly and De Visscher, supra note 22, pp. 253-259; Research on International Law Under the Auspices of the Harvard Law School, supra note 22, p. 543; Hans Lauterpacht, (ed.), Oppenheim's International Law, vol. I (Longmans, London, 1967) p. 333; Hans Lauterpacht, 'Allegiance, Diplomatic Protection and Criminal Jurisdiction over Aliens', 9 Cambridge Law Journal (1945-1947) p. 343. 156) See Daneil M. Segesser, 'The International Debate on the Punishment of War Crimes During the Balkan Wars and the First World War', 31 Peace and Change (2006) pp. 537-538; James W. Garner, 'Punishment of Offenders Against the Laws and Customs of War', 14 American Journal of International Law (1920) pp. 77-79; Baxter, supra note 84, p. 383.
} 
Numerous commentators during and after the war recognised the validity of the protective principle over war crimes, as well as over crimes against peace and crimes against humanity. ${ }^{157}$ In this regard, it is useful to refer to the commentary of Lauterpacht, who was a member of the International Commission for Penal Reconstruction and Development during World War II, whose work informed the enactment by the Allies of national laws at the end of the war. ${ }^{158}$ Lauterpacht examined in detail the right under international law to punish enemy war criminals. According to Lauterpacht:

\begin{abstract}
With regard to acts committed in the territory of the adversary, like the maltreatment of prisoners of war, the belligerent may, in applying his municipal law to war criminals, rely on the rule, which many states have adopted and which general international law has not stigmatised as illegal, that a state may punish criminal acts committed by foreigners abroad against its own safety or against its nationals. ${ }^{159}$
\end{abstract}

Thus, Lauterpacht was of the view that, "there exists a broader basis, in addition to the fact of an uncontroverted custom of warfare, for the rule of international law which concedes to belligerents the right to punish such war criminals as may fall into his hands." That basis is one of protection. Even the UNWCC recognised the right of a belligerent to punish war crimes against its nationals to be "an undoubted right of international law" ${ }^{160}$ The right of the injured State to punish war crimes was also recognised in a Memorandum of the U.N. Secretary-General and a unanimous resolution adopted by the U.N. General Assembly at its First Session, immediately after the war. ${ }^{161}$

The State practice at the end of World War II is undoubtedly an important development of international criminal law and of the protective principle of jurisdiction. Indeed, since the modern codification of the law of war in the midnineteenth century, there existed no general provisions as to the right to punish

157) See Edward D. Dickinson et al., 'Report of the Sub-Committee [of the International and Comparative Law Section of the American Bar Association] on the Trial and Punishment of War Criminals', 37 American Journal of International Law (1943) p. 665; Wright, supra note 112, p. 49; Carnegie, supra note 21, p. 410; Röling, supra note 144, pp. 172-175, 201; Kevin J. Heller, The Nuremberg Military Tribunals and the Origins of International Criminal Law (Oxford University Press, Oxford, 2011) Chap. 5; Roger O'Keefe, 'The Grave Breaches Regime and Universal Jurisdiction', 7 Journal of International Criminal Justice (2009) p. 822; Baxter, supra note 84, p. 385; Treves, supra note 102.

158) Lauterpacht, supra note 110. For discussion of Lauterpacht's work in his capacity as one of the members of the International Commission for Penal Reconstruction and Development, see History, supra note 10, p. 94.

159) Ibid., p. 63.

160) Law Reports, vol. XV, p. 26.

161) Memorandum Submitted by the Secretary-General, 'Historical Survey of the Question of International Criminal Jurisdiction', (1949) (U.N. Doc. A/CN.4/7 Rev.1) p. 1; U.N. General Assembly Resolution 3(I) Extradition and Punishment of War Criminals, First Session on 13 February 1946. 
its violations or on individual criminal responsibility; moreover, though the right to punish violations of the law of war was regarded, as a matter of custom, as belonging to the injured State, problems with obtaining custody of the accused meant that prosecutions had been few and far between. ${ }^{162}$

\section{The Collective Exercise of Protective Jurisdiction over a Common Enemy}

During the trial of enemy war criminals, there occurred many instances of the exercise of jurisdiction by one Ally for the prosecution of war crimes and crimes against humanity against the nationals of other Allied nations. The basis of this jurisdiction may be explained as an expansion of the protective principle, which was exercised by some of the Allies, and in certain cases collectively, over a common enemy in one and the same war. This interpretation of jurisdiction is shared by a numerous other commentators. ${ }^{163}$ It is also supported by some of the national laws enacted by the Allies, ${ }^{164}$ and many of the trials of war criminals. ${ }^{165}$ The idea of collective punishment by each of the injured Allies is also indicated by the creation of the UNWCC, which had specifically as its role the investigation of war crimes by "enemy forces or civilians against nationals of the United Nations ... during the present war". ${ }^{166}$ The right under international law of the Great Powers to set up military tribunals in their respective zones of occupied Germany, pursuant to Law No. 10, in order to collectively punish a common enemy for crimes against their own and other Allied nationals was defended by a U.S. Military

162) 'First, Second and Third Interim Reports from the Committee of Enquiry into Breaches of the Laws of War', supra note 29, p. 22; Richard R. Baxter, 'So-Called 'Unprivileged Belligerency': Spies, Guerrillas and Saboteurs', 21 British Yearbook of International Law (1951) p. 324; Pictet, supra note 96, p. 352; Meron, supra note 115, pp. 553-554, 571.

163) See Bowett, supra note 28; Dapo Akande "The Protective Principle"; "The Active Nationality Principle"; "The Passive Personality Principle"; "The Territoriality Principle", in Antonio Cassese (ed.), The Oxford Companion to International Criminal Justice (Oxford University Press, Oxford, 2009) p. 474; Machteld Boot, Nullem Crimen Sine Lege and the Subject Matter Jurisdiction of the International Criminal Court: Genocide, Crimes Against Humanity and War Crimes (Intersentia, Antwerpen, 2002) p. 211; Röling, supra note 144, pp. 172-175, 201; O'Keefe, supra note 157, pp. 822-823; Heller, supra note 157, p. 130.

164) E.g., Australian War Crimes Act, Article 12; the Chinese Law Governing the Trial of War Criminals, Article 8; the Norwegian Law on the Punishment of Foreign War Criminals, Article 1; the Netherlands Decree on Extraordinary Penal Law, Article 4, as amended by the Act of 19 July 1947, Article 27; the Yugoslav Law on war crimes and treasonable activities, Article 3.

165) See The Belsen Trial, Law Reports, vol. II; Trial of General Tomoynki Yamashita, Law Reports, vol. IV, pp. 3-4, 35; The Hostages Trial, Law Reports, vol. VIII, p. 54; The Dachau Concentration Camp Trial, Law Reports, vol. XI, p. 10; Trial of Wilhelm Gerbsch, Law Reports, vol. XIII, p. 135; Law Reports, vol. XV, p. 43 and the cases cited therein; In re SS Member Ablbrecht (No 1), 14 ILR 196, pp. 197-198; In re Rohrig et al., supra note 84; Röling, supra note 144, p. 175.

166) War Cabinet, 'War Crimes', 14 November 1944, National Archives, cab/66/57/48; see also Trial of Susuki Motosuke, Law Reports, vol. XIII, pp. 127-8; History, supra note 10, p. 105. 
Tribunal In Re Oblendorf and Others. ${ }^{167}$ In that case, the 21 German defendants were accused of war crimes and crimes against humanity against Jews, Gypsies and Soviet political officials, "aimed at the destruction of foreign nations". The tribunal inter alia stated that,

[f]rom time immemorial there have existed rules, laws and agreements which kept opposing forces within bounds in the matter of the conduct of warfare ... Those who violated these rules were subject to trial and prosecution by both the country whose subjects they were and by the country whose subjects they maltreated. ${ }^{168}$

The tribunal went on to explain, however, that there is no authority which denies a number of belligerents from agreeing to punish a common enemy for crimes against each other's nationals, and asserted that:

no one would be so bold as to suggest that what occurred between Germany and Russia from June 1941 to May 1945 was anything but war, and, being war, that Russia would not have the right to try the alleged violators of the rules of war on her territory and against her people. And if Russia may do this alone, certainly she may concur with other nations who affirm that right. ${ }^{169}$

The expansion of the protective principle of jurisdiction, for the punishment of crimes under Law No. 10 by a common enemy against Allied nationals, was, concluded the tribunal, "not only in conformity with International Law but is in itself a highly significant contribution to written International Law." 170

In the Trial of Eisentrager and Others, a U.S. Military Commission sitting in China convicted German enemy nationals for the breach of surrender terms against the United States and its Allies, in violation of the laws and customs of war. ${ }^{171}$ The commission inter alia rejected the argument that it lacked jurisdiction over war crimes committed by German nationals on Chinese territory, on the ground that China "had invited the United States to send military forces to China in order to defeat a common enemy". ${ }^{172}$ Perhaps the clearest example of the collective exercise of an expanded principle of protective jurisdiction was the establishment of International Military Tribunals at Nuremberg and Tokyo, which were composed of several Allied nations for the punishment of 'major' war criminals for crimes against peace, war crimes and crimes against humanity. ${ }^{173}$

\footnotetext{
167) 15 ILR 656.

168) Ibid., p. 663.

169) Ibid., p. 659.

170) Ibid.

171) Law Reports, vol. XIV, p. 8.

172) Law Reports, vol. XIV, pp. 15-16; see also Trial of Lieutenant General Shigeru Sawada et al., Law Reports, vol. V, pp. 9-10.

173) Dapo Akande, 'The Jurisdiction of the International Criminal Court over Nationals of NonParties: Legal Basis and Limits', 1 Journal of International Criminal Justice (2003) pp. 627-628;
} 
These Tribunals were created on the basis of agreement for the punishment of a common enemy, "whose offences ha[d] no particular geographical location", ${ }^{174}$ which had injured each of the Allies composing the Tribunals. This was recognised, albeit impliedly, by the Judgment of the Nuremberg Tribunal, which declared that the Allies had, in accordance with international law, "done together what any one of them might have done singly". ${ }^{175}$ As regards the Far East, the major proponent for the establishment of the Tokyo Tribunal was the U.S. for retribution against Japan's leadership for the attack on Pearl Harbour, which had initially preferred a small trial relating to that attack and was thus of the view that it could punish Japan's leaders "singly". ${ }^{176}$ This interpretation of jurisdiction is consistent with State practice at the end of the war, but it also comports with the recommendation by the Commission at the end of World War I for the establishment of a "High Tribunal" by several of the Allies who had each been injured by violations of the law of war by a common enemy. ${ }^{177}$ The American representatives to the Commission inter alia also made clear that military tribunals of the Allies "affected" by war crimes "may be united, thus forming an international tribunal" for the trial and punishment of "the persons belonging to enemy countries", where such persons have "committed outrages against a number of civilians and soldiers of several Allied nations". ${ }^{178}$ The jurisdiction of these tribunals is not capable of supporting the development of universality. ${ }^{179}$ It therefore appears that the exceptional circumstances of the war and the need for each of the injured Allies to punish injuries by a common enemy provided the necessary solidarity in order to overcome, albeit temporarily, serious political and ideological tensions between the Soviet bloc and the West. ${ }^{180}$

John Stanton, 'Canada and War Crimes. Judgment at Tokyo', 55 International Journal (19992000); Yves Sandoz, 'The History of the Grave Breaches Regime', 7 Journal of International Criminal Justice (2009) p. 673; Wright, supra note 112, p. 49.

174) Moscow Declaration, supra note 79.

175) Judgment of the Nuremberg Tribunal, supra note 105, p. 216. See also Judgment of the International Military Tribunal for the Far East, supra note 91, per Concurring Opinion by the Honourable Mr. Justice Delfin Jaranilla, p. 650.

176) Boister and Cryer, supra note 91, p. xxxvii.

177) 'Commission on the Responsibility of the Authors of the War and on Enforcement of Penalties', supra note 110, pp. 121-124. See also Bellot, supra note 29, p. 53.

178) Ibid., pp. 141-142.

179) Draper, supra note 112, p. 155; Report of the Commission on the Use of the Principle of Universal Jurisdiction by some Non-African States as Recommended by the Conference of Ministers of Justicel Attorney's General, supra note 7, para. 14. See also "Memorandum of Proposals" submitted by Judge Rosenmann to a Meeting Attended by Mr. Eden, Mr. Settinius and Mr. Moltov at San Francisco on 3rd May, 1945', Annexed to War Cabinet, 18 May 1945, National Archives, cab/66/65/63.

180) See Francine Hirsch, 'The Soviets at Nuremberg: International Law, Propaganda, and the Making of the Postwar Order', 113 American Historical Review (2008). 
This exercise of jurisdiction has led many courts and commentators, including the UNWCC and Lord Wright, to assert that it was based on universality. ${ }^{181}$ However, this view has been adopted uncritically; it is based on tentative, secondary sources, or else primary sources which have been interpreted wholly out of context. This is illustrated by the following example. Kontorovich has asserted that the tribunals of several Allies relied on universal jurisdiction to justify their proceedings, and gave judicial sanction to the analogy of war crimes with piracy in support of universality. ${ }^{182}$ In support of this argument, Kontorovich did not examine the trials of war criminals and instead cited the case of Demjanjuk v. Petrovsky ${ }^{183}$ However, the court in that case did not undertake any primary research either and, in support of universality, cited the Restatement (Third). The Restatement merely cited erroneous secondary literature to support its assertion that "It is generally agreed that the establishment of these tribunals [the Nuremberg Tribunal and the tribunals in occupied Germany under Law No. 10] and their proceedings were based on universal jurisdiction". ${ }^{184}$ What is more, the Reporters' Note inter alia stated, rather unconvincingly, that universality was accepted over war crimes and genocide after World War II, "although apparently no state has exercised such jurisdiction in circumstances where no other basis for jurisdiction ... was present" ${ }^{185}$ The Restatement (Third) is also inconsistent with its predecessor, the Restatement (Second), published in 1965, which did not recognise universality over these crimes. ${ }^{186}$ As has already been discussed above, the creation by the Great Powers of the International Military Tribunals and the tribunals in their respective zones of occupied Germany are incapable of supporting universal jurisdiction. Although it is not realised by Kontorovich, none of the tribunals to which he refers gave judicial sanction to universal jurisdiction or to the analogy of war crimes with piracy; this was, in fact, done by the UNWCC in its interpretation of these cases and, it will be recalled from the discussion above, in reliance not on State practice but rather the argument made by Cowles.

181) Demjanjuk, supra note 1; Memorandum Submitted by the Secretary-General, supra note 14, p. 80; Law Reports, vol. XV, pp. 43-44; John Pritchard, 'The International Military Tribunal for the Far East and its Contemporary Resonances', 149 Military Law Review (1995) p. 33; Henry T. King, 'Universal Jurisdiction: Myths, Realities, Prospects, War Crimes and Crimes Against Humanity: The Nuremberg Precedent', 35 New England Law Review (2000-2001) pp. 282-284; Wiliam B. Simons, 'The Jurisdictional Bases of the International Military Tribunal at Nuremberg', in Ginsburgs and Kudriavtsev, supra note 63, p. 15; Morris, supra note 1, pp. 341-342; Heller, supra note 157, p. 129; Meron, International Criminalisation, supra note 1; Randall, supra note 1; Scharf, supra note 1, p. 369; Cryer et al., supra note 1, p. 45; Sadat, supra note 14, p. 245; Brand, supra note 98, p. 416; Treves, supra note 102, p. 576.

182) Kontorovich, supra note 1, p. 195.

183) Demjanjuk, supra note 1, p. 177.

184) Restatement (Third), supra note 1, para. 404.

185) Ibid., Reporters' Note One.

186) American Law Institute, 'Restatement (Second) of Foreign Relations Law', (1965), para. 34. 
This distorted interpretation of the evolution of universal jurisdiction is commonplace in the literature. ${ }^{187}$ The same may be said of the trial of war criminals in the Far East; Pritchard, who has published extensively on the proceedings of Tokyo Tribunal and is regarded by many as authoritative, has asserted that it "firmly established" universal jurisdiction, without providing any evidence in support. ${ }^{188}$

Universal jurisdiction was not recognised in any of the trials at the end of the war. ${ }^{189}$ Rather, jurisdiction was restricted to crimes by a common enemy which had a nexus with the prosecuting State or Allied nations in one and the same war. Nor was universality recognised by the preparatory work undertaken on the subject of jurisdiction by the official and semi-official inter-Allied bodies during the war. ${ }^{190}$ The absence of State practice in support of universality is significant. Even the UNWCC was not wholly convinced that jurisdiction was based on universality. To be sure, in all of the cases reported by the UNWCC where universality was listed as one of the possible bases of jurisdiction over war crimes and crimes against humanity, the UNWCC also reasoned that the jurisdiction of the prosecuting State was justified under international law on the alternative ground that it "has a direct interest in punishing the perpetrators of crimes if the victim was a national of an ally engaged in a common struggle against a common enemy". ${ }^{191}$ Notably, this alternative interpretation of jurisdiction by the UNWCC was ignored by Lord Wright and has generally been overlooked by subsequent courts and commentators. This gives rise to a further issue; there exist important inconsistencies between the UNWCC and Lord Wright, despite both relying upon the work of Cowles. Unlike the UNWCC, universality was not claimed to exist by Lord Wright over crimes against humanity; on the other hand, neither the UNWCC nor Lord Wright recognised universality over crimes against peace. It is not clear why one crime was found to be based on universality, while others were not. These inconsistencies never were explained away by Lord Wright. Moreover, they are reflected in later legal scholarship.

What is often assumed as universality by courts and commentators was in fact an expanded principle of protection between Allies in one and the same war. The reason for this development of the protective principle was alluded to by the Dutch Special Court of Cassation:

\footnotetext{
187) E.g., Randall, supra note 1; Scharf, supra note 1; Benoit, supra note 1, p. 271; Jordan J. Paust, 'Universality and the Responsibility to Enforce International Criminal Law: No U.S. Sanctuary for Alleged Nazi War Criminals', 11 Houston Journal of International Law (1988-1989) p. 340.

188) Pritchard, supra note 181.

189) See also Draper, supra note 112, p. 155.

190) See the conclusions of the International Commission on Penal Reconstruction and Development and the London International Assembly, in History, supra note 10, p. 109.

191) The Almelo Trial, Law Reports, vol. I, p. 42; The Hadamar Trial, Law Reports, vol. I, p. 53; The Zyklon B Case, Law Reports, vol. I, p. 103.
} 
$[T]$ he concurrence of two different national jurisdictions was permissible in cases where members of the armed forces of the enemy, who had violated, as such, the laws and customs of war, were tried after the cessation of hostilities by the competent tribunals of the other belligerent in whose power they might have remained, or to whom they might have been extradited for that purpose in accordance with an international agreement. Such trial of war criminals by the injured party after the war had come increasingly to the fore, particularly since the First World War, as a result of the experience that the belligerent powers (especially Germany) could not be relied upon to fulfil their obligation themselves to punish those members of their armed forces who had transgressed the laws and customs of war. The obvious objections to this state of affairs had led since the First World War to the rapid development of international law in the direction of personal responsibility for war crimes and to the trial of those responsible either by an international tribunal or by tribunals of the injured belligerent. ${ }^{192}$

The rationale underlying the development of the protective principle was thus based on the necessity of the injured belligerent to punish violations of the law of war and, in turn, to protect its vital interests. During World War II, the Allies were well aware that crimes were a part of official State policy and therefore the enemy could not be entrusted to fulfil its obligations under international law, by prosecuting breaches of the law of war by their own armed forces and civilians. ${ }^{193}$ The broader rationale underlying the protective principle was to prevent the impunity of perpetrators of crimes under international law, where crimes had some nexus with the prosecuting State or with Allied nations. To that end, the protective jurisdiction of the injured belligerent, as was asserted by the Dutch Court of Cassation inter alia, was concurrent with that of the enemy. ${ }^{194}$ It was thus the importance of ensuring that threats and injuries to vital State interests did not go unpunished why it was important to prevent impunity. This clearly is at odds with the proponents of universal jurisdiction, which is said to be based solely on preventing the impunity of perpetrators of international crimes because of their 'heinous' nature. However, the war crimes trials do not give rise to any indication that the prevention of impunity had anything to do with crimes under international law as being 'heinous', or that jurisdiction was exercised over such crimes solely on the basis that they were 'heinous'. Accordingly, the prevention of impunity of the perpetrators of 'heinous' crimes is incapable of providing a theoretical basis for universality over war crimes. As jurisdiction over war crimes was based on the protective principle, clearly there was also not an absence of any accepted basis of jurisdiction recognised by international law, which is so often relied upon by commentators, rather simplistically, in support of the emergence of universality. ${ }^{195}$

192) In re SS Member Ablbrecht (No 1), 14 ILR 196, pp. 197-198; see also The Hostages Trial, Law Reports, vol. VIII, p. 54.

193) See The Hostages Trial, ibid., p. 27; The Hadamar Trial, Law Reports, vol. I, p. 53.

194) See also The Hostages Trial, ibid., p. 54; In re Ohlendorf and Others, 15 ILR 656.

195) See Carnegie, supra note 21, p. 423; Cowles, supra note 15, p. 194; Randall, supra note 1; Scharf, supra note 1, p. 371; Kontorovich, supra note 1, p. 195; Claus Kre $\beta$, 'Universal Jurisdiction 


\section{Protective Jurisdiction and the Right of Self-Defence}

The broader justification for the protective principle would appear to be based on the right under international law of self-defence. As was explained by Hall, "[a] belligerent, besides having the rights over his enemy which flow directly from the right to attack, possesses also the right of punishing persons who have violated the laws of war" ${ }^{196}$ The relationship between self-defence and protective jurisdiction was explained by Chief Justice Stone before the U.S. Supreme Court in the case of Ex Parte Quirin and Others in the following terms:

An important incident to the conduct of war is the adoption of measures by the military command, not only to repel and defeat the enemy, but to seize and subject to disciplinary measures those enemies who, in their attempt to thwart or impede our military effort, have violated the law of war. ${ }^{197}$

The right to punish violations of the law of war was qualified to "those enemies who ... attempt to thwart or impede our military effort". This suggests that violations of the law of war are injurious to the adversary, by impeding its "military effort", and that the protective jurisdiction of the offended State is a part of selfdefence. The reasoning of the court inter alia was affirmed by Chief Justice Stone before the U.S. Supreme Court in re Yamashita, which upheld jurisdiction to try and punish members of the enemy "at war with the United States of America and its allies" for violations of the law of war against "the people of the United States and its allies and dependencies". ${ }^{198}$ This protective jurisdiction over violations of the law of war, asserted Chief Justice Stone, operates both during war "as a preventative measure against such violations" and after the cessation of hostilities as an "inherent power to guard against immediate renewal of the conflict" and to punish injuries which military operations had produced. ${ }^{199}$ In the Trial of Eisentrager and Others, a U.S. Military Commission sitting in China held that "[o]ne of the corollaries of waging war ... is the punishment of those that violate the laws of war." 200 The commission inter alia appeared to be of the view that the collective waging of war by the Allies in self-defence against a common enemy entailed a right of collective protective jurisdiction.

over International Crimes and the Instiut de Droit International, 4 Journal of International Criminal Justice (2006) p. 575.

196) Hall, supra note 110, p. 395; also Judgment of the International Military Tribunal for the Far East, supra note 91, per Judgment of the Honourable Mr. Justice Pal, p. 830.

197) 317 U.S. 1, p. 28.

198) Law Reports, vol. IV, pp. 3-4, 35, 41-42.

199) Ibid., pp. 41-42.

200) Law Reports, vol. XIV, pp. 15-16; see also Trial of Lieutenant General Shigeru Sawada et al., Law Reports, vol. V, pp. 9-10. 
Lord Wright observed both of the aforementioned Supreme Court decisions, which laid down, he asserted, the following principle under international law: " $t \mathrm{t}]$ he nation attacked is entitled to defend itself, and it is incidental to that that it should be entitled to punish those individuals who are guilty of the aggression if they fall within its custody" ${ }^{201}$ Notably, Lord Wright not only alluded to the relationship between the protective principle and self-defence, but he relied upon the same reasoning to justify the expansion of the protective principle to include crimes against peace. According to Lord Wright, States "are entitled to resist unlawful aggressions against their own freedom and independence; hence when the aggressive state goes beyond its own boundary and its own domestic affairs in order to interfere with the freedom and independence of other sovereign states, the latter are entitled to resist and punish aggressor" ${ }^{202}$ Although this argument made by Lord Wright was controversial at the time, given that the concept of crimes against peace under international law was regarded by many as an innovation, ${ }^{203}$ there is little doubt the Allies, in creating this crime and holding liable under international law individuals belonging to the enemy, were punishing injuries to their own sovereignty, security, independence and certain other of their vital interests. The Nuremberg Tribunal dedicated the majority of its Judgment to discussing the waging by Germany of aggressive wars against the Allies, which it described as the "supreme international crime". ${ }^{204}$ As regards the Far East, the Cairo Declaration of 1 December 1943 issued by the United States, Britain and China declared that " $[t]$ he Three Great Allies are fighting this war to restrain and punish the aggression of Japan". ${ }^{205}$ The jurisdiction of the Tokyo Tribunal was expressly restricted to the punishment of crimes by persons who had also waged war against one or more of the Allies. ${ }^{206}$ The indictment against the defendants before the Tokyo Tribunal also makes clear that the Allies were concerned with punishing a common enemy for using military force to exclude them from trading with China and for waging aggressive wars against their colonies in the Far East. ${ }^{207}$ It reasonable to suppose therefore that jurisdiction was based on the protective principle. ${ }^{208}$

\footnotetext{
201) History, supra note 10, p. 20.

202) Ibid., p. 18.

203) See Judgment of the International Military Tribunal for the Far East, supra note 91, per Dissenting Opinion of Mr. Justice Röling, p. 700; per Judgment of the Honourable Mr. Justice Pal, ibid., p. 830; see also Kirsten Sellars, 'William Patrick and "Crimes Against Peace" at the Tokyo Tribunal, 1946-1948', 15 The Edinburgh Law Review (2011).

204) Judgment of the Nuremberg Tribunal, supra note 105, p. 186.

205) Supra note 91.

206) Special Proclamation-Establishment of an International Military Tribunal for the Far East, supra note 93, Article 1; Charter of the International Military Tribunal for the Far East, Article 5, in Boister and Cryer, supra note 91, p. 7.

207) Indictment (counts 1-36), ibid., p. 16.

208) See also Heller, supra note 157, pp. 129-130.
} 


\section{Protective Jurisdiction and the Enforcement of International Law}

There is a further consideration as regards the use of protective principle over crimes under international law. As was explained by Lauterpacht, it must be realised that the injured belligerent punishes war criminals under the protective principle but also enforces the law of nations:

For acts committed by members of the armed forces of the belligerent in the course of hostilities can be treated by the municipal law of the adversary as criminal acts only if there is no justification for them in international law, that is to say, they are contrary to the law of war ... War criminals are punished, fundamentally, for breaches of international law. ${ }^{209}$

There is thus a distinction to be made between crimes under international law, which is applicable to all States, and the right to punish its violations by the injured State under the protective principle. This distinction was recognised by Lauterpacht and was explained in the case of The Justice Trial, which has already been discussed above. This distinction is of crucial importance, which has been overlooked by the proponents of universal jurisdiction, and will be returned to below.

It is the enforcement of international law which has led commentators, including the UNWCC, to mistakenly assume that war crimes and other crimes under international law are subject to universal jurisdiction. ${ }^{210}$ Thus, the practice typical to Anglo-American countries, such as Britain, Canada and the U.S., suggested the UNWCC, is to apply directly international law and "to stress the breach of the laws and usages of war ... and the violation of any set of legal rules other than the laws and usages of war need not be shown." 111 These States did not therefore regard it as necessary to expressly specify under their municipal law any head of prescriptive jurisdiction recognised by international law in order to punish crimes under international law. This approach to jurisdiction was used by the International Military Tribunals at Nuremberg and Tokyo and under Law No. 10, and was also endorsed by the UNWCC, probably under the influence of the U.S. and Britain. ${ }^{212}$ At first glance, this seemingly gives the appearance of jurisdiction as

\footnotetext{
209) Supra note 110 , p. 64.

210) Meron, supra note 1, p. 572; Roger O'Keefe, 'Universal Jurisdiction: Clarifying the Basic Concept', 2 Journal of International Criminal Justice (2004) p. 756; J. M. Wagner, 'US Prosecution of Past and Future War Criminals and Criminals Against Humanity: Proposals for Reform Based on the Canadian and Australian Experience', 29 Virginia Journal of International Law (1989) p. 887; A. T. Richardson, 'War Crimes Act 1991', 55 Modern Law Review (1992) pp. 76-78; Michael P. Scharf, 'The ICC's Jurisdiction over the Nationals of Non-Party States: A Critique of the U.S. Position', 64 Law and Contemporary Problems (2001) p. 82; Paust, supra note 187.

211) Law Reports, vol. III, Annex II, pp. 81-82; see also Annex I-III generally, ibid.; Law Reports, vol. XI, Annex; Pictet, supra note 96, p. 353.

212) History, supra note 10, p. 12. See also Judgment of the Nuremberg Tribunal, supra note 105, para. 51; Ex Parte Quirin and Others 317 U.S. 1, p. 29.
} 
being neutral and objective, absent of any nexus, and exercised in the interest and on behalf of the "entire world community". ${ }^{213}$ On closer inspection, however, violations of international law were punished, and international law was thus enforced, in carefully selected ways by the offended State. This was observed after World War I by the 'Committee of Enquiry into the Breaches of the Laws of War', which found that Britain had no jurisdiction under its municipal law to prosecute war crimes by foreign nationals on the high seas or abroad, even though they had been committed against British nationals; nevertheless, it found that Britain had the right, as the offended State, to enforce international law directly over the enemy, which was implied in the laws and customs of war. ${ }^{214}$ This suggests that the protective principle is built-in to the law of war. It would explain why the vast majority of trials at the end of World War II reported by the UNWCC, as well as the Judgments of the Nuremberg and Tokyo Tribunals, did not expressly defend their right under international law to prosecute war crimes, or crimes against peace and crimes against humanity; moreover, generally, no attempt was made to explain the vital State interests which had been injured and instead stress was placed on the breach of the laws and customs of war. The traditional approach of Anglo-American States as to jurisdiction over crimes under international law is related more to the way that international law is received in municipal law. ${ }^{215}$ It has nothing to do with universality.

The enforcement of international law suggests that breaches of the law of war, as violations of international law, in and of themselves, were regarded as injurious, and sufficient to establish jurisdiction, by the prosecuting State. It is perhaps understandable that a belligerent bound by the rules of warfare would find it injurious if its adversary would benefit from them without also being so bound. It is reasonable to suppose, however, that offended States, by prosecuting war crimes, were seeking to punish threats or injuries to their sovereignty and certain other of their vital interests, including security, political independence and governmental functions. Once it is realised that war crimes are injurious in and of themselves, it matters not whether such crimes are committed "systematically" and on a "large scale" in order to be subject to the jurisdiction under the protective principle. ${ }^{216}$ Moreover, the passive personality principle of jurisdiction over war crimes immediately becomes unsatisfactory and irrelevant. ${ }^{217}$

\footnotetext{
213) Simons, supra note 181, p. 52; Carnegie, supra note 21, p. 423; Randall, supra note 1, p. 810.

214) 'First, Second and Third Interim Reports from the Committee of Enquiry into Breaches of the Laws of War, with Appendices', supra note 29, pp. 13-28.

215) See Rv. Jones and Others [2006] UKHL 16, per Lord Bingham, para. 22.

216) For a contrary view, see Carnegie, supra note 21, p. 412.

217) Numerous commentators have argued that jurisdiction over war crimes and crimes against humanity is based on the passive personality principle of jurisdiction; see Bassiouni, supra note 14, pp. 118-119; Carnegie, ibid., p. 422; Cryer et al., supra note 1, p. 43; Sponsler, supra note 1, p. 47; Heller, supra note 157, pp. 128-129.
} 
The enforcement by States of international law also suggests that international law itself recognises that breaches of the law of war are injurious to vital State interests, which are common to the international community, and that it has, as one of its roles, through the law of war, their protection. It does so by regulating the conduct of States in their relations with each other during war and by "prohibiting resort to certain methods of waging war" 118 and imposing limitations upon "means of injuring the enemy". ${ }^{219}$ With the absence of an international police force, however, the injured State is permitted by international law to punish its violations under the protective principle, should the perpetrators fall into its hands. This would also explain the reason why international law has traditionally permitted the offended State to resort to reprisals against its 'enemy' for violations of the laws and customs of war. ${ }^{220}$ Of course, this is not to suggest that the rules of warfare are, and have been, at least since their modern codification in the mid-nineteenth century, of a progressive humanitarian character, with their object being to impose limitations upon the use of violence to protect human rights during war. ${ }^{221}$ However, to focus on the protection of the rights of the individual alone, as do the advocates of universal jurisdiction, would appear to show less than full appreciation of the realities of the legal situation. ${ }^{222}$ The breach of the law of war by the enemy violates the human rights of the individuals concerned, but it no less injures the vital State interests of the adversary. It is not really credible or realistic to say that States prosecute war crimes solely for the protection of human rights. It has to be realised that the law of war also serves to reciprocally protect during war the vital State interests of belligerents. ${ }^{223}$

218) Judgment of the Nuremberg Tribunal, supra note 105, p. 218. See also Baxter, supra note 84; Baxter, supra note 162; Jean S. Pictet (ed.), Commentary. III Geneva Convention Relative to the Treatment of Prisoners of War (ICRC, Geneva, 1960) p. 5.

219) St Petersburg Declaration, Declaration Renouncing the Use, in Time of War, of Explosive Projectiles Under 400 Grammes Weight (29 November 1868), Preamble; Project of an International Declaration concerning the Laws and Customs of War, Brussels (27 August 1874), Article 12; Hague Convention (IV) with Respect to the Laws and Customs of War on Land (18 October 1907), Preamble \& Article XXII.

220) See The Trial of Albert Kesserling, Law Reports, vol. VIII, pp. 3-5 and the authorities cited therein; Trial of Willy Zuehlke, Law Reports, vol. XIV, p. 144; 'First, Second and Third Interim Reports from the Committee of Enquiry into Breaches of the Laws of War, with Appendices', supra note 29, p. 22; Bellot, supra note 29, pp. 34-35.

221) 'First, Second and Third Interim Reports from the Committee of Enquiry into Breaches of the Laws of War, with Appendices', ibid., para. 23; St. Petersburg Declaration of 1868, Preamble, supra note 219; Hague Convention IV, Preamble, supra note 219; Mahmoud C. Bassiouni, International Criminal Law. A Draft International Criminal Code (Sijthoff \& Noordhoff, the Netherlands, 1980) p. 77; Hirsch Lauterpacht, 'The Limits of the Operation of the Law of War', 30 British Yearbook of International Law (1953).

222) Bassiouni, ibid., pp. 6, 12, 43; Hirsch Lauterpacht, 'The Problem of Revision of the Law of War', 29 British Yearbook of International Law (1952) p. 362.

223) See also Robin Gieb and Michael Siegrist, 'Has the armed conflict in Afghanistan affected the rules on the conduct of hostilities?', 93 International Review of the Red Cross (2011) p. 21; 
Conceptually, the law of war has as its basis a compromise between the protection of mutual vital State interests of each of the warring parties and humanitarian concerns. ${ }^{224}$

It is with these considerations in mind that it can be properly understood the following assertion by the U.S. Military Tribunal in The Hostages Trial:

An international crime is such an act universally recognised as criminal, which is considered a grave matter of international concern and for some valid reason cannot be left within the exclusive jurisdiction of the state that would have control over it under ordinary circumstances. The inherent nature of a war crime is ordinarily itself sufficient justification for jurisdiction to attach in the courts of the belligerent into whose hands the criminal has fallen, the jurisdiction being concurrent. ${ }^{225}$

Commentators have frequently cited this statement wholly out of context as universal jurisdiction. ${ }^{226}$ However, the tribunal in that case did not recognise the existence of universal jurisdiction. The "valid reason" that war crimes could not be left within the exclusive jurisdiction of the State whose subjects have committed such acts, as has already been discussed above, is that Germany could not be entrusted to fulfil its obligations under international law. The reason the tribunal inter alia stated that the "inherent nature of the war crime" is "sufficient justification" for the jurisdiction of the "belligerent into whose hands the criminal has fallen, the jurisdiction being concurrent", was because it recognised that war crimes are "common law crimes", that is, crimes under international law and binding upon all States, but also because they "violated the rules of warfare" and are in and of themselves injurious. ${ }^{27}$ Thus, while the tribunal asserted that war crimes, as violations of international law, are "universally recognised as criminal", in justifying its own jurisdiction, sitting in the U.S. zone of Germany under Law No. 10, over the 'enemy' defendants in that case, it was careful to stress that the right to punish such crimes was restricted to the "belligerent into whose hands the accused has fallen". However, the jurisdiction of the "belligerent into whose hands the criminal has fallen" meant "the one whose subjects were the victims of the alleged crimes or an allied power." 228 It is for this reason the tribunal in the present case went on to state that the "only adequate remedy" is the concurrent

\footnotetext{
Alfred P. Rubin, 'Actio Popularis, Jus Cogens and Offences Erga Omnes', 35 New England Law Review (2000-2001) p. 275.

224) See Neil Lamp, 'Conceptions of War and Paradigms of Compliance: The 'New War' Challenge to International Humanitarian Law', 16 Journal of Conflict and Security Law (2011).

225) Law Reports, vol. VIII, p 54 (italics added); see also In re Rohrig et al., supra note 84, p. 395.

226) For example, Carnegie, supra note 21, p. 421; Heller, supra note 157, p. 129; Kreß, supra note 195, p. 575; Randall, supra note 1, pp. 807-808.

227) Supra note 225.

228) See The Dachau Concentration Camp Trial, Law Reports, vol. XI, p. 10; Trial of Generaloberst Nickolaus von Falkenhorst, Law Reports, vol. XI, p. 29; Public Prosecutor v. Klinge, 13 ILR 263, pp. 263-264; In re Oblendorf and Others, 15 ILR 656.
} 
jurisdiction of the captor belligerent, who may "surrender the alleged criminal to the [Allied] state where the offence was committed, or, on the other hand, it may retain the alleged criminal for trial under its own legal process." ${ }^{229}$ Similarly, In re Eisentrager, a U.S. Military Commission sitting in China, in justifying its jurisdiction over war crimes by German citizens in Chinese territory, asserted that "A war crime ... is not a crime against the law or criminal code of any individual nation, but a crime against the jus gentium. The laws and usages of war are of universal application, and do not depend upon national laws and frontiers." Yet the commission inter alia restricted the right of jurisdiction over war crimes to the injured State or one of its Allies in one and the same war. ${ }^{230}$ The emphasis placed on international law seems to have been in order to demonstrate that such conduct was unlawful and to justify the enforcement of jurisdiction over the enemy. This interpretation of jurisdiction is consistent with the conclusion of the Commission at the end of World War I, which stated, on the one hand, that a crime under international law is "an act universally recognised as criminal, which is considered a grave matter of international concern", and, on the other, the right of the injured Allies to punish such crimes. There was thus recognised a crucial distinction between the universal application of the law of war, as part of international law, and the right under international law of the injured State to punish its violations under the protective principle. It is to this crucial distinction that the article will now turn.

\section{The Protection of Vital State Interests 'Shared' by the International Community}

There was a crucial distinction in State practice in the aftermath of World War II, which was explained by several cases during the trials of war criminals, between the law of war, which is part of international law and therefore of universal application, and the right under international law of the injured State, or one of its Allies, to punish its violations under the protective principle. The importance of this distinction was explained, perhaps most eloquently, in the case of The Justice Trial. The tribunal in that case, it will be recalled, asserted the "universality" and "superiority" of the law of war, as part of international law, to that of municipal law, but made it clear that the right to punish violations of the law of war and enforce international law, in order to protect "cherished doctrines of national sovereignty", was restricted by international law to that of the "injured" belligerent. ${ }^{231}$ Moreover, the tribunal was careful to note that it was not overriding

\footnotetext{
229) Supra note 225.

230) Law Reports, vol. XIV, p. 15.

231) Supra note 136, p. 37.
} 
established principles of international law and that, "[o]nly by giving consideration to the extraordinary and temporary situation in Germany can the procedure here be harmonised with established principles of national sovereignty." 232 The tribunal was referring here to the fact that it was sitting in the U.S. zone of occupied Germany under Law No. 10 and that the one sovereignty involved, namely the German Reich, had surrendered unconditionally to the Great Powers. The same may be said as to the creation of International Military Tribunals in Nuremberg and Tokyo, as both of the relevant States had surrendered unconditionally. The Allies, in prosecuting crimes under international law, were thus careful to ground jurisdiction in pre-existing international law, and thereby ensuring to protect, rather than to "diminish" or "obliterate", the concept of sovereignty. ${ }^{233}$ Thus, the fact that the Allies stressed that particular conduct was regarded as criminal under international law, and therefore of 'international concern' and took precedence over any inconsistent domestic laws of the enemy, does not mean that it was subject to universal jurisdiction. ${ }^{234}$ The prevention of impunity for perpetrators of crimes under international law was undoubtedly important but only by reason that States were also punishing injuries to their own, or that of their Allies, sovereignty and security and certain other vital interests by persons belonging to the 'enemy'.

This raises a further important issue: the proper role of international law within the international community. The basis of jurisdiction over crimes under international law provides for a more profound understanding of the role of international law within the international community and the values that it seeks to protect. It would appear that international law has as one of its most fundamental roles the balancing of vital State interests shared by the international community and which it seeks to protect and, in turn, the prevention of inter-State conflict. This balance may be framed in the following terms: international law protects sovereignty and certain other vital State interests from the excessive interference by other States, by restricting the scope and application of their extraterritorial jurisdiction; this is balanced by the right under international law of the injured State to punish violations of the law of war in order to protect its own sovereignty and certain other vital interests. This balance is important in relation to the debate

232) Ibid., p. 38.

233) Osofsky, supra note 14, p. 205; King, supra note 181, pp. 282-283.

234) See also Draper, supra note 112, p. 155; Bowett, supra note 28; Boot, supra note 163, p. 213; Bottini, supra note 14, p. 515; Carnegie, supra note 21, p. 421; Guenael Mettraux, 'Dutch Courts' Universal Jurisdiction over Violations of Common Article 3 qua War Crimes', 4 Journal of International Criminal Justice (2006) p. 367; David Scheffer, 'Opening Address', 35 New England Law Review (2000-2001); Sienho Yee, 'Universal Jurisdiction: Concept, Logic, and Reality', 10 Chinese Journal of International Law (2011) p. 507; Rv. Bow Street Magistrates' Court and Others, ex parte Pinochet Ugarte, [1998] All ER (D) 629, per Lord Slynn, p. 14; Arrest Warrant, supra note 3, per Separate Opinion of President Guillaume, pp. 42-44; per Declaration of Judge Ranjeva, ibid. 
in recent years on universal jurisdiction, whose proponents have argued instead that the role of international law is to balance the prevention of impunity with sovereignty.

The idea that universal jurisdiction developed over war crimes and other crimes under international law in the aftermath of World War II is one which has been driven mainly by inaccurate scholarly opinion, and is deeply unsatisfactory. It gives insufficient consideration to the development of jurisdiction under the protective principle; more seriously, it conflates the distinction between jurisdiction based on the protection of vital State interests, which are shared by the international community, with universality. In particular, it is based on the premise that States act as "agents of the international community" and punish war crimes to protect the "fundamental interests", "values" or "vital interests" of the international community. ${ }^{235}$ It is far from clear as to what these values consist; however, one such value identified by commentators, the prevention of impunity of the perpetrators of international crimes, as an end in and of itself, is falsely elevated to a position of superior consideration. ${ }^{236}$ And, more fundamentally, international law is misunderstood as having as its role the protection of values of the international community. ${ }^{237}$ Consequently, it is often assumed that war crimes are subject to universal jurisdiction by mere virtue of the fact that they are crimes

235) See Eichmann, supra note 1, p. 300; Arrest Warrant, supra note 3, per Joint Separate Opinion of Judges Higgins et al., p. 79; per Dissenting Opinion of Judge van den Wyngaert, ibid., p. 141; per Dissenting Opinion of Judge Al-Khasawneh, ibid.; Pinochet, supra note 14, per Lords BrowneWilkinson and Millett; AU-EU Expert Group, supra note 4, para. 9; Institut de Droit International, supra note 5; 'Observations by Belgium on the scope and application of the principle of universal jurisdiction', para. 4, <www.un.org/en/ga/sixth/65/ScopeAppUniJuri.shtml>, 8 April 2012; Ian Brownlie, Principles of Public International Law (Oxford University Press, Oxford, 1998) p. 308; Bruce Broomhall, 'Towards the Development of an Effective System of Universal Jurisdiction for Crimes Under International Law', 35 New England Law Review (2001) p. 403; Neil Boister, 'Transnational Criminal Law', 14 European Journal of International Law (2003) pp. 963-966; Antonio Cassese, 'Is the Bell Tolling for Universality? A Plea for a Sensible Notion of Universal Jurisdiction', 1 Journal of International Criminal Law (2003) p. 591; Georges Abi-Saab, 'The Proper Role of Universal Jurisdiction', 1 Journal of International Criminal Justice (2003) pp. 599-600; Santiago Villalpando, 'The Legal Dimensions of the International Community', 21 European Journal of International Law (2010) p. 406; Donnedieu de Vabres, 'The System of Universal Jurisdiction', 9 Journal of International Criminal Justice (2011) p. 925; Baxter, supra note 162, pp. 385-386; Bassiouni, supra note 14, p. 104; Bassiouni, supra note 221, Chap. I; Kobrick, supra note 14, p. 1522; Kre $\beta$, supra note 195, p. 567; O’Keefe, supra note 157, p. 824; Puast, supra note 187, p. 340; Simmons, supra note 181, p. 137; Wright, supra note 14, p. 280.

236) Villalpando, ibid., pp. 413, 416; Kreß, ibid., p. 571; Arrest Warrant, ibid., per Dissenting Opinion of Judge van den Wyngaert, pp. 153-156, 166-167; S-G Report, supra note 3, p. 4; Redress, 'Extraterritorial Jurisdiction in the European Union. A Study of the Laws and Practice in the 27 Member States of the European Union' (December 2010), p. 19, <www.fidh.org/IMG/pdf/ Extraterritorial_Jurisdiction_In_the_27_Member_States_of_the_European_Union_Final.pdf $>$, 20 April 2012.

237) See Arrest Warrant, ibid., per Joint Separate Opinion of Judges Higgins et al. 
under international law. ${ }^{238}$ This is also often accompanied by claims of the diminution of State sovereignty and the mistaken assumption that international criminal law and State sovereignty are "enemies". 239

It is necessary therefore, it is submitted, to reconceptualise jurisdiction over war crimes, and, indeed, the role of international law, by making a crucial distinction between the protection of vital State interests, which are shared by the international community, and universality. Notably, this distinction was overlooked by the U.N. General Assembly in its unanimous "affirmation" of the principles of international law recognised by the Nuremberg Charter and Judgment, ${ }^{240}$ and also by International Law Commission in the subsequent formulation of the "Nuremberg Principles" and in its draft code of "Offences against the Peace and Security and Mankind", both of which included the punishment of war crimes. Principle 1 of the Nuremberg Principles, which were adopted by the International Law Commission in 1950, provided that "[a]ny person who commits an act which constitutes a crime under international law is responsible therefore and liable to punishment". ${ }^{241}$ This principle was adopted wholly out of the context from which it was derived and overlooks completely that the right to punish crimes under international law belongs to the injured State under the protective principle. Although the Nuremberg Principles did not recognise the right of universal jurisdiction, and ultimately were not adopted by the General Assembly, they have nevertheless been subsequently interpreted as the implicit affirmation

238) Eichmann, supra note 1; Princeton Principles, supra note 4, pp. 29, 45; Tadic, supra note 14, para. 62; Jurisdictional Immunities of the State (Germany v. Italy: Greece intervening), ICJ Reports 2012, per Dissenting Opinion of Judge Cançado Trindade, pp. 15-16, <www.icj-cij.org/>, 20 April 2012; International Law Association, supra note 1, p. 3; Institut de Droit International, Article 3(a), supra note 5; Redress, supra note 236; Benoit, supra note 1, p. 262; Boister, supra note 235; O’Keefe, supra note 157, pp. 823-824; O’Keefe, supra note 210; Kre $\beta$, supra note 195, p. 575; Langer, supra note 1, p. 3; Paust, supra note 187, p. 340; Luc Reydams, 'Universal Jurisdiction over Atrocities in Rwanda: Theory and Practice', 1 European Journal of Crime, Criminal Law and Criminal Justice (1996) p. 23; Christopher Stephen, 'International Criminal Law: Wielding the Sword of Universal Criminal Justice', 61 International Comparative Law Quarterly (2012); Luis Parga Peraza, 'The Concept of Universal Jurisdiction: A Reality in the Making', The Westminster International Law \& Theory Centre Online Working Papers, 2009/1.

239) Rob Cryer, 'International Criminal Law vs State Sovereignty: Another Round?', 16 European Journal of International Law (2005) pp. 988-989; e.g., see Larry May, Crimes Against Humanity. A Normative Account (Cambridge University Press, Cambridge, 2005) p. 8; Kirsten Sellars, 'Imperfect Justice at Nuremberg and Tokyo', 21 European Journal of International Law (2010); King, supra note 181, pp. 282-283; Osofsky, supra note 14, p. 205; Parga Peraza, ibid., p. 4.

240) U.N. General Assembly resolution 95(I), Affirmation of the Principles of International Law recognised by the Charter of the Nuremberg Tribunal, 11 December 1946; U.N. General Assembly resolution 177(II), Formulation of the Principles Recognised in the Charter of the Nuremberg Tribunal and in the Judgment of the Tribunal, 21 November 1947.

241) Report of the International Law Commission to the General Assembly in the work of its Second Session, 5 June-29 July 1950, Official Records of the General Assembly, Fifth Session, Supplement No. 12 (A/1316), reproduced in Yearbook of the International Law Commission, 1950, vol. II, p. 374. 
that crimes under international law, including war crimes, must be subject to universal jurisdiction. ${ }^{242}$

The first case to rely upon the Nuremberg Principles and invoke universal jurisdiction over war crimes, was that of Eichmann in 1961. This case is notable because it has been relied upon almost exclusively by the proponents of universal jurisdiction over war crimes and crimes against humanity. ${ }^{243}$ Yet, rather surprisingly, it has been overlooked time and again that the Nazi and Nazi Collaborators (Punishment) Act of 1951 which conferred upon Israeli municipal courts extraterritorial jurisdiction over war crimes, crimes against the Jewish people and crimes against humanity did not provide for universal jurisdiction; rather, it provided that war crimes had to be "done, during the period of the Second World War, in an enemy country", while the other crimes listed within the Act had to be "done, during the period of the Nazi regime, in an enemy country". The national law of Israel was thus subject to the same jurisdictional limitations as that of the other Allies and, given that it was concerned with crimes committed against Jews, was likewise based on the principle of protection. Indeed, the District Court inter alia found that jurisdiction was valid under the protective principle, as crimes against the Jewish people "very deeply concerns the "vital interests" of the State of Israel"; ${ }^{244}$ what is more, the Supreme Court of "fully agree[d] with every word said by the [District] Court" and "upheld its criminal and penal jurisdiction by virtue also of the 'protective' principle". ${ }^{245}$ Although Israel did not exist as a sovereign State at the time of Eichmann's alleged crimes, the issue was whether Israel could claim that its "fundamental interests existing at that time had been so threatened by the prior Nazi holocaust as to justify the application of the protective principle." ${ }^{246}$ Nevertheless, the Supreme Court of Israel in that case, relying in part upon the academic commentary by Cowles, and misinterpreting State practice in the aftermath of World War II and the affirmation of the Nuremberg Principles by the U.N. General Assembly, held that crimes under international law are subject to universal jurisdiction. The Supreme Court was of the view that

242) See Arrest Warrant, supra note 3, per Dissenting Opinion of Judge van den Wyngaert, p. 154; $R$ v. Bow Street Metropolitan Stipendiary Magistrate and Others, Ex parte Pinochet Ugarte (No. 3), [2000] 1 A.C. 147, per Lord Browne-Wilkinson, pp. 197-198; per Lord Millett, ibid., pp. 272-274; Benoit, supra note 1, p. 262; Meron, supra note 1, p. 22; Parga Peraza, supra note 238, p. 2.

243) AU-EU Expert Group, supra note 4, para. 9; Report of the Commission on the Use of the Principle of Universal Jurisdiction by some Non-African States as Recommended by the Conference of Ministers of Justice/Attorney's General, supra note 7, paras. 14 \& 19; Memorandum by the Secretariat, Immunity of State officials from foreign criminal jurisdiction, International Law Commission, Sixtieth Session, 2008 (U.N. Doc. A/CN.4/596) p. 15; Kenneth Roth 'The Case for Universal Jurisdiction', 80 Foreign Affairs (2001) p. 151; Benoit, supra note 1, p. 273; King, supra note 181, p. 284; Langer, supra note 1, p. 2; Osofsky, supra note 14, p. 196; Randall, supra note 1, p. 810; Scharf, supra note 1, p. 370.

244) Attorney-General for Israel v. Eichmann, 36 ILR 5 (District Court), pp. 49-57.

245) Eichmann, supra note 1, p. 304.

246) Treves, supra note 102, p. 589. 
crimes under international law are of "universal character", and therefore are subject to universal jurisdiction. It regarded universality as a logical outcome of the Nuremburg Principles. Moreover, it conflated the distinction between the protection of vital State interests shared by the international community with the protection of "an agreed vital interest of the international community" and claimed to be acting as an "agent of the international community". ${ }^{247}$ The decision of the Supreme Court to rely on universality and claim to act on behalf of the international community for the protection of the vital interests of the international community may have been influenced more by the way in which Israel had abducted Eichmann from Argentina and the resultant scrutiny of the trial by the international community, and the fact that Israel was not in existence at the time of Eichmann's crimes. This latter point was acknowledged as such by the Supreme Court in the following terms: "[t]hat being the case, no importance attaches to the fact that the State of Israel did not exist when the offences were committed". Yet, it is precisely the fact that Israel lacked universal jurisdiction and that the defendant had during the war belonged to the 'common enemy' and was a senior official, whose name had been included in a list of war criminals wanted by the UNWCC and was even mentioned in the Judgment of the Nuremberg Tribunal, ${ }^{248}$ that Israel's right to assert jurisdiction, in the words of Lord Millett, 'never has been questioned'. ${ }^{249}$

Despite the Eichmann case, the conceptualisation of jurisdiction as based on the protection of vital State interests shared by the international community has been reflected in some of the most important developments in international law as well as State practice ever since World War II. It is useful to consider some examples in order to illustrate this point.

The crime of genocide under international law is regarded as one of the most serious and 'heinous', yet the drafters of the Genocide Convention considered and rejected universal jurisdiction as it would be "against the traditional principles of international law and [...] might therefore create dangerous international tensions." ${ }^{250} \mathrm{~A}$ further example is the jurisdictional regime over war crimes adopted through the grave breaches provisions common to the 1949 Geneva Conventions. ${ }^{251}$ Many commentators, who have accepted that universal jurisdiction did not emerge during the trial of war criminals in the aftermath of World War II, have argued instead, rather unconvincingly, that universality developed under Geneva Conventions. ${ }^{252}$ Some commentators have argued, rather

247) Eichmann, supra note 1, p. 300.

248) Judgment of the Nuremberg Tribunal, supra note 105, p. 252; Law Reports, vol. XIV, p. 93.

249) Pinochet, supra note 14, pp. 68-69.

250) Cited in the Memorandum Submitted by the Secretary-General, supra note 14, p. 33.

251) Articles 49(I); 50(II); 129(III); 146(IV); and Article 85 of Additional Protocol I of 1977.

252) Report of the Commission on the Use of the Principle of Universal Jurisdiction by some Non-African States as Recommended by the Conference of Ministers of JusticelAttorney's General, supra note 7; 
simplistically, that the Geneva Conventions must be based on universal jurisdiction, based on the expression "regardless of their nationality". ${ }^{253}$ To accept this interpretation is to believe that States had a complete change of mind as to the basis of jurisdiction over war crimes, almost overnight, from the protective principle to that of universality. This is unlikely, given that universality had no foundation in State practice at that time. In any case, the nationality of the accused and of the victim is just as irrelevant under the protective principle. The grave breaches provisions, as explained by the authoritative commentary of Pictet, place upon High Contracting Parties three obligations. ${ }^{254}$ The first of these is to enact under municipal law the necessary legislation in order, for the first time, "to create a certain uniformity of legislation" and "establish what these grave breaches were, in order to be able to ensure universality of treatment in their repression." 255 As explained by Pictet, prior to the Geneva Conventions, "States were left completely free to punish, or not, acts committed by their own troops against the enemy, or, again, acts committed by enemy troops, in violation of the laws and customs of war". ${ }^{256}$ The second obligation is that each State search for alleged offenders who may be on its territory and, if successful, try any person accused of a grave breach. ${ }^{257}$ This has to be read in conjunction with the final obligation, which provides that each High Contracting Party may, "if it prefers", hand the accused over for trial "to another High Contracting Party concerned". The inclusion of this latter obligation indicates that States do not believe grave breaches are subject to universal jurisdiction, which has been borne out by the practice of States over the past sixty years. ${ }^{258}$ States had the opportunity to use the principle of universal jurisdiction in the grave breaches provisions but chose not to do so. ${ }^{259}$ The grave breaches provisions are, in fact, a treaty-based example of the principle aut dedere aut judicare. ${ }^{260}$ It has to be understood that the principle of aut dedere

AU-EU Expert Group, supra note 4, para. 9; Antonio Cassese, 'On the Current Trends Towards Criminal Prosecution and Punishment of Breaches of International Humanitarian Law', 9 European Journal of International Law (1998) p. 5; Theodore Meron, 'War Crimes in Yugoslavia and the Development of International Law', 88 American Journal of International Law (1994) p. 80; Bassiouni, supra note 14, pp. 117-188; King, supra note 181, p. 283; Meron, supra note 115, p. 572; Sandoz, supra note 169.

253) Richard Van Elst, 'Implementing Universal Jurisdiction Over Grave Breaches of the Geneva Conventions', 13 Leiden Journal of International Law (2000) pp. 820-821; O'Keefe, supra note 157, pp. 822-823.

254) Pictet, supra note 96, pp. 358, 362.

255) Ibid., pp. 264, 370.

256) Ibid., p. 352.

257) Ibid., p. 366.

258) Rubin, supra note 223, p. 269; Cassese, supra note 252, p. 5; Sandoz, supra note 173, p. 675; Arrest Warrant, supra note 3, per Joint Separate Opinion of Judges Higgins et al., p. 76; per Separate Opinion of President Guillaume, ibid., pp. 42-44.

259) Bowett, supra note 28; Arrest Warrant, ibid., per Joint Separate Opinion of Judges Higgins et al., pp. 71-72.

260) Pictet, supra note 96, p. 358; Bowett, ibid. 
aut judicare is not a basis of jurisdiction under international law. ${ }^{261}$ Rather, it is a treaty mechanism used as a means of exercising jurisdiction; it ensures, at least in theory, that a State injured by an offence is able to have the accused sent back for trial, or else tried on its behalf by the territorial State. It is for this reason that Grotius first developed the principle; thus, he argued that the unwillingness of Portugal to punish its own nationals for crimes committed against the Dutch justified the waging of war by the Dutch against Portugal in order to punish the offenders. ${ }^{262}$ The use of this principle in the Geneva Conventions has to be read in light of the quickly deteriorating political alliances in the aftermath of the war, in particular, between Western Allies and the Soviet bloc with the emergence of the Cold War, and the resultant practical difficulties faced by injured States in obtaining custody of accused 'enemy' war criminals seeking refuge in "in the territories of certain States". ${ }^{263}$ The same issue of obtaining custody of accused war criminals had arisen at the end of the World War I, which resulted in "a handful of trials and in inadequate sentences" ${ }^{264}$ Thus, the grave breaches provisions are designed to be mutually beneficial, by enabling injured States to punish, or have punished by a foreign power, war crimes, regardless of the nationality of the accused and the political alliances of the custodial State. If these conventions do codify customary international law, as has been suggested by many commentators, then it may be said that they codify the right of the injured State to prosecute, or have prosecuted on its behalf, grave breaches.

Lastly, it is useful to consider briefly some examples of State practice as regards the prosecution of war crimes. In the late 1980s, the interest of a small number of States in the prosecution of war crimes was revived after it became apparent that numerous Nazi 'enemy' war criminals from World War II had subsequently acquired citizenship in these respective countries, which included Canada, Australia and Britain. It is interesting that these States enacted legislation for the prosecution of war crimes and crimes against humanity and, in so doing, claimed to be acting under the principle of universal jurisdiction. ${ }^{265}$ It seems to have been

\footnotetext{
261) Yee, supra note 234, p. 513.

262) Hugo Grotius, Commentary on the Law of Prize and Booty (Martine J. Van Ittersum (ed.), Indianapolis, Liberty Fund, 2006) pp. 428-429.

263) See resolution 3(I), adopted unanimously by the U.N. General Assembly; resolution of the Inter-American Conference on Problems of War and Peace of 1945; History, supra note 10, p. 413; L. C. Green, 'Canadian Law, War Crimes and Crimes Against Humanity', 59 British Yearbook of International Law (1988) p. 218; Luc Reydams, 'The Rise and Fall of Universal Jurisdiction', Leuven Centre for Global Governance Studies, Working Paper No. 37 (2010) p. 17.

264) War Cabinet, 'Treatment of War Criminals', 22 June 1942, National Archives, cab/66/25; Cabinet, 'Reply to Holland (Extradition of the Ex-Emperor)', Cabinet Papers 639, 13 February 1920, National Archives, cab/24/98; War Cabinet, 'Warning to Neutrals Not to Grant Asylum to Enemy Leaders and War Criminals, W.P. (44) 484, 30 August 1944, National Archives, $\mathrm{cab} / 66 / 54 / 34$.

265) See Christopher Greenwood, 'The War Crimes Act 1991', in Hazel Fox and Michael A. Meyer (eds.) Effecting Compliance (The British Institute of International Law, London, 1993) p. 222; Green, supra note 263, p. 229.
} 
forgotten by these States that they had not actually used universal jurisdiction in the aftermath of World War II. In any case, this legislation does not, in fact, provide for universal jurisdiction over war crimes and crimes against humanity either, being limited to crimes by persons belonging to a 'common enemy' during the period of the Second World War, in which these States were engaged, and who are subsequently residing in the territory of the prosecuting State. ${ }^{266}$ The jurisdictional basis of these legislative provisions, and the handful of trials brought under them, was thus arguably based on the protective principle. ${ }^{267}$

In more recent years, the few European States which previously claimed universal jurisdiction, and who have proclaimed to have "pioneered" this principle, ${ }^{268}$ have taken a dramatic about-turn and imposed significant limitations on the scope of extraterritorial jurisdiction over war crimes. The municipal law of Spain under Article 23(4) of the 1985 Organic Law of the Judicial Power was interpreted by the Spanish Constitutional Court as providing for universal jurisdiction over a range of international crimes, including war crimes, to protect the interests that "affect the international community as a whole". ${ }^{669}$ This differed sharply with a number of previous decisions by the Spanish Supreme Court, which had interpreted this provision as requiring the existence of a "point of connexion with national interests", so that "no State may unilaterally establish order through criminal law, against everyone and the entire world". ${ }^{270}$ This "point of connection with national interests" was considered necessary by the Supreme Court to legitimise the use of extraterritorial jurisdiction over crimes under international law and avoid an over-extension of national criminal jurisdiction, which could otherwise conflict with other principles of international law, including sovereignty and non-interference in internal affairs, and give rise to problems in Spain's international relations. The Supreme Court also observed that there has in recent years been a trend to limit the scope of jurisdiction in the legislation of other European countries, by requiring some connection with the prosecuting State. ${ }^{271}$ Notably, the Supreme Court's interpretation of Article 23(4) as requiring the existence of a "point of connexion with national interests" or that Spaniards are the victims of crimes, which may be understood to be a formulation of the

260) See Arrest Warrant, supra note 3, per Joint Separate Opinion of Judges Higgins et al., p. 69.

267) Polyukhovitch, supra note 1; Demjanjuk, supra note 1; The Queen v. Finta [1994] S.C.R. 701 (Can); $R$ v. Sawoniuk (Central Criminal Court 1999) (unpublished); Fédération Nationale des Déportés et Internes Résistants et Patriotes and Others v. Barbie 78 ILR 125 (Fr. Cass. Crim. 1983).

268) 'Observations by Belgium on the scope and application of the principle of universal jurisdiction', supra note 235, para. 13.

269) Guatemalan Generals case, S.T.C. No. 237/2005, 26 September 2005 (Constitutional Court).

270) Guatemalan Generals case, No. 327/2003, 25 February 2003 (Supreme Court); see also Scilingo case S.T.S. No. 1362/2004, 15 November 2004 (Supreme Court); Jiménez Sánchez and Others v. Gibson and Others, No 1240/2006, 11 December 2006 (Supreme Court) ILDC 993 (ES 2006). 271) Ibid. 
protective principle, was codified in Spanish national law in 2009. ${ }^{272}$ However, it is useful to note that, even before this legislative reform, it would appear that the Spanish Constitutional Court's interpretation of 'universal' jurisdiction was really based on the protective principle, given that the relevant case involved crimes against Spanish civilians and an attack against a Spanish embassy and its employees and a Spanish ambassador. ${ }^{273}$ The German Code of Crimes Against International Law of 26 June 2002, by virtue of section 153(f), provides that prosecutors may decide not to prosecute war crimes if the accused is not present in Germany or the offence has not been committed against a German. The Belgian Law of 5 August 2003 significantly limited the scope of extraterritorial jurisdiction of Belgium over war crimes to circumstances where the victim of the offence is a Belgian citizen. This is reflective of the U.S. War Crimes Act of 1996. ${ }^{274}$ In addition to restricting the scope of national legislation providing for extraterritorial jurisdiction over crimes under international law, by requiring some jurisdictional nexus, States have also given themselves broad political discretion over prosecutions, so that jurisdiction will only be exercised where there is some nexus. ${ }^{275}$ A further notable tendency is that the few, particularly European countries which have claimed to apply universal jurisdiction have done so selectively, mainly in relation to offences committed by or against their own citizens or residents, or where the offence has occurred in a former colonial country, and thus where there is some link with the prosecuting State. ${ }^{276}$ It may thus be reasonably questioned whether jurisdiction over war crimes can really be claimed to be universal.

\section{The Protection of the "Fundamental Values" of the International Community}

Some commentators have sought to give legitimacy to universal jurisdiction by arguing that the principle has evolved as part of a normative framework and linking it with the concepts jus cogens and obligations erga omnes, irrespective of State practice in the aftermath of World War II. ${ }^{277}$ This argument is based on the idea

\footnotetext{
272) Organic Law 1/2009, 3 November. See Enrique C. Rojo, 'National Legislation Providing for the Prosecution and Punishment of International Crimes in Spain', 9 Journal of International Criminal Justice (2011) pp. 710-720.

273) Guatemalan Generals case (Constitutional Court), supra $\mathrm{n} 269$.

274) 18 U.S.C., section 2441(b) (Supp. 1996).

275) See the Police Reform and Social Responsibility Act of 2011, section 153; Belgian Law of 5 August 2003; German Code of Crimes Against International Law of 26 June 2002.

276) See S-G Report, supra note 3; Bottini, supra note 14, pp. 504-505; Langer, supra note 1; Raydams, supra note 263, pp. 26-27.

277) Harmen van der Wilt, 'Universal Jurisdiction under Attack. An Assessment of African Misgivings towards International Criminal Justice as Administered by Western States', 9 Journal
} 
that crimes under international law are of a jus cogens character and constitute an attack on the "fundamental values" of the international community; in turn, each and every State forming part of the international community has an obligation erga omnes to prosecute the perpetrators of such crimes. ${ }^{278}$ The failure of a State to prosecute such crimes either in its own territory or by its nationals, so the argument goes, is a breach of obligations erga omnes and therefore any other State is permitted on the basis of universal jurisdiction to protect the international community's "fundamental values". It is useful therefore to examine briefly the concepts of jus cogens and erga omnes.

The concept of jus cogens first appeared in modern international law in the 1969 Vienna Convention on the Law of Treaties and provides that "[a] treaty is void if ... it conflicts with a peremptory norm of general international law ... accepted and recognized by the international community of states as a whole". ${ }^{279}$ The International Court of Justice (hereafter ICJ) has identified as jus cogens the prohibition of inter-State force, which it also believed to be "a fundamental or cardinal principle" of customary international law, ${ }^{280}$ and more recently war crimes and crimes against humanity. ${ }^{281}$ However, the Court inter alia has not explained the reason why it regarded these crimes as peremptory norms. Beyond these categories, there is little agreement as to what peremptory norms of international law are accepted by the international community. The concept erga omnes was introduced by the dictum of the ICJ in the Barcelona Traction case, where the Court proclaimed that:

... an essential distinction should be drawn between the obligations of a State towards the international community as a whole, and those arising vis-à-vis another State ... By their very nature the former are the concern of all States. In view of the importance of the rights involved, all States can be held to have a legal interest in their protection; they are obligations erga omnes. ${ }^{282}$

The Court inter alia identified what it considered as examples of erga omnes obligations, which were acts of aggression, genocide and the protection of individuals from slavery and racial discrimination. ${ }^{283}$ That case did not concern obligations

of International Criminal Justice (2011) pp. 4-5; Andre de Hoogh, Obligations Erga Omnes and International Crimes. A Theroeteical Inquiry into the Implementation and Enforcement of the International Responsibility of States (Kluwer, London, 1996) p. 54; Mahmoud C. Bassiouni, 'International Crimes: Jus Cogens and Obligatio Erga Omnes', 59 Law and Contemporary Problems (1996) p. 66; Randall, supra note 1, pp. 830-831.

278) Yee, supra note 234, p. 505.

279) Vienna Convention on the Law of Treaties, 23 May 1969, Article 53.

280) Case Concerning Military and Paramilitary Activities in and Against Nicaragua (Nicaragua v. United States) (Merits) ICJ Reports 1986, para. 190, <www.icj-cij.org/>, 20 April 2012.

281) Germany v. Italy, supra note 238, para. 95.

282) Case Concerning the Barcelona Traction, Light and Power Company Limited (Belgium v. Spain), Second Phase, ICJ Reports 1970, para. 33, <www.icj-cij.org/>, 20 April 2012.

283) Ibid., para. 34 . 
erga omnes and it was a civil case; perhaps understandably, therefore, the Court provided little analysis of this concept or of how it came into being; nor did the Court explain why it regarded these crimes as erga omnes, or put forward any reasoning or criteria for determining whether a certain obligation is of an erga omnes character. Given the apparent lack of understanding of the concepts of jus cogens and erga omnes in the reasoning of the ICJ, and that the "fundamental interests" of the international community are inherently vague and abstract, ${ }^{284}$ it may be the case that these concepts are better interpreted to mean the protection of vital State interests shared by the international community. This interpretation would apply to the Court's example of aggression, given that it threatens sovereignty, territorial integrity and independence and security, all of which are vital State interests shared by the international community. Less clear is how this interpretation would apply to the other offences identified by the Court, namely genocide and the protection of individuals from slavery and racial discrimination. These issues are beyond the scope of the present work; the point is that the uncertainty and ambiguity surrounding the concepts of jus cogens and erga omnes, particularly in the reasoning of the ICJ, suggests that caution should be exercised as to how much weight is given to them.

More to the point, even if all States can be said to have a legal interest in the protection of the international community's "fundamental interests", it does not follow that the protection of such interests is based on universal jurisdiction, even if a particular crime may be said to be of a jus cogens character. ${ }^{285} \mathrm{~A}$ crime under international law, which by definition is of universal application and concern, given that international law is binding on all States, does not mean that all States have a right to exercise universal jurisdiction over it. Since the Barcelona Traction case, the ICJ has not recognised that an act in breach of an obligation erga omnes and of a jus cogens character as being capable of giving rise to universal jurisdiction. In the Arrest Warrant, the Court held, albeit without express reference to the concepts of jus cogens and erga omnes, that it did not recognise any exception to the inviolability of an incumbent State official accused of war crimes and crimes against humanity. ${ }^{286}$ In the Advisory Opinion on the Israeli Wall, the Court held that Israel was in breach of obligations erga omnes for constructing a wall in Occupied Palestinian Territory and therefore "all States are under an obligation not to recognise the illegal situation"; however, the Court did not recognise the right of universal jurisdiction over such breaches. If the opinio juris of States was that crimes under international law breach obligations erga omnes and are of a jus

284) See de Hoogh, supra note 277, p. 45.

285) Report of the Commission on the Use of the Principle of Universal Jurisdiction by some Non-African States as Recommended by the Conference of Ministers of Justice/Attorneys General, supra note 7, paras. 8, 35; Higgins, supra note 21, p. 57; Rubin, supra note 223; Yee, supra note 234.

286) Arrest Warrant, supra note 3, paras. 58, 78; see also Germany v. Italy, supra note 238. 
cogens character and therefore are capable of giving rise to universal jurisdiction, then this perhaps would have been recognised by States in the International Law Commission's Draft Articles on State Responsibility, ${ }^{287}$ or agreed in the formulation of the jurisdiction of the International Criminal Court (hereafter ICC).

The interpretation of the concepts erga omnes and jus cogens as permitting a right of universal jurisdiction has developed almost entirely, if not exclusively, out of legal scholarship de lege ferenda. In the Guatemalan Generals case, the Spanish Constitutional Court employed the jus cogens line of reasoning to uphold the validity of the concept of universal jurisdiction, yet it was only able to cite "legal scholars" in support of this proposition. ${ }^{288}$ It may be one thing to proclaim that crimes under international law are erga omens and jus cogens, but it is a great conceptual leap to suggest that these concepts permit and give legitimacy to universal jurisdiction under customary international law. It may be argued, with equal force, that certain vital State interests shared by the international community and protected by international law, such as sovereignty and sovereign equality and independence, non-interference in internal affairs and the inviolability of incumbent State officials, have the status of erga omnes and jus cogens. Thus, the question may fairly be posed whether it really is credible to invoke these concepts in order to justify universal jurisdiction and, in turn, override principles of international law which are capable of equally having the same status and character. On the contrary, wherever there is a conflict between perceived "fundamental values" of the international community and vital State interests shared by the international community, there has been a marked reluctance in State practice to proclaim the primacy of the former. ${ }^{289}$ Whatever may be the scope and application of jus cogens and erga omnes, which remain controversial, contested and equivocal, stretching them beyond their reasonable interpretation and the authority which they are capable of supporting, without any debate or agreement by States, as have the proponents of universal jurisdiction, risks undermining their validity and international law. Ultimately, relying upon jus cogens and erga omnes substitutes one misinterpretation of the evolution of universal jurisdiction, namely in the aftermath of World War II, for another.

Perhaps a more persuasive argument made in support of the possible evolution of a permissible right of universal jurisdiction over war crimes in customary international law, irrespective of State practice in the aftermath of World War II, is the subsequent reference made by States to universality. ${ }^{290}$ This has been described as a "modern positivist" understanding of the process of international law-

287) See Article 48 and the commentary therein, reprinted in James Crawford (ed.), The International Law Commission's Articles on State Responsibility (Cambridge University Press, Cambridge, 2002) p. 276.

288) Guatemalan Generals case (Constitutional Court), supra note 269, para. 5.

289) Villalpando, supra note 235, pp. 413, 415.

290) E.g., see Kre $\beta$, supra note 195 , pp. 573-576. 
making, which focuses on the evolution of customary international law by placing significant weight on "verbal State practice", rather than "hard" State practice. ${ }^{291}$ It is not the purpose of the present work to assess generally the method of ascertaining customary international law through this approach, or to undertake a thorough analysis of the present state of the law. Rather, the question is whether universal jurisdiction should be regarded as having evolved over war crimes in 'verbal' State practice and capable of being a valid right of customary international law, irrespective of actual State practice at the end of World War II. On close inspection, however, this is far from clear. Cases such as Eichmann and Demjanjuk, which have already been discussed above, relied heavily upon State practice in the aftermath of World War II in order to give legitimacy to claims of universal jurisdiction, despite misinterpreting that practice as being based on universal jurisdiction. Both of these cases are specific and context dependent, with a focus on the prosecution of crimes by persons belonging to a 'common enemy'; moreover, jurisdiction was based on the protective principle. It is also doubtful that Israel or the U.S. would accept the validity of universal jurisdiction over war crimes in a different context, or if the accused involved their own nationals and were being prosecuted by another State. ${ }^{292}$ One would possibly have to accept these cases at a superficial level in order to rely on them as evidence or precedents for the evolution of 'verbal' State practice in support of a permissive right of universal jurisdiction under customary international law. An alternative interpretation is that these cases have served to entrench misunderstanding as to the basis of jurisdiction over war crimes.

Beyond these cases, a cautious approach should be adopted in relying on verbal State practice to support the evolution of universal jurisdiction over war crimes in customary international law, as claims may be lofty, inconsistent and even based on misinterpretations and erroneous assumptions as to what is the concept of universal jurisdiction; indeed, many States claim the right of universal jurisdiction over war crimes but, on closer inspection of their national laws and military manuals, it is apparent that they are really referring to the mechanism of extradite or prosecute, which is a wholly different concept. ${ }^{293}$ It should thus be of little surprise that States may make verbal claims as to the right of universal jurisdiction and then do something quite different in actual practice. On the other hand, States may claim an all-encompassing and expansive right of universality over war crimes, even though there is a link with the prosecuting State and other jurisdictional principles, including the protective principle, are applicable. This is illustrated by the 1998 Pinochet case, in which Spain's National Court Criminal Division upheld on the basis of universal jurisdiction an arrest warrant issued by

291) Kre $\beta$, ibid., p. 573.

292) E.g., see Reydams, supra note 263, pp. 21-22.

293) See Henckaerts and Doswald-Beck, supra note 111, Chap. 44, Part B. 
a Spanish investigative judge against Pinochet for 'terrorism', genocide and torture, even though more than 50 Spanish nationals had been among the victims which was held to give Spain a "legitimate interest in the exercise of such jurisdiction". ${ }^{294}$ In the Scilingo case, the alleged victims of international crimes included Spanish nationals and the Spanish Supreme Court held that this gave Spain a "national interest" in the exercise of universal jurisdiction, which effectively amounted to the affirmation of the protective principle. ${ }^{295} \mathrm{It}$ is also illustrated in a wholly different context, namely the response by maritime powers in recent years to the problem of piracy in the Gulf of Aden, which are claiming expansive jurisdiction under universality in order to protect their own vital trade routes and merchant shipping, without having to prove evidentially any nexus with accused pirates. A crucial question is the way in which verbal State practice in support of the evolution of universal jurisdiction over war crimes is informed; States may make reference to a customary right of universal jurisdiction over war crimes by relying upon secondary sources, which are themselves inaccurate and based on misinterpretations. ${ }^{296}$ This latter point is further illustrated by the two following examples.

The ICRC in its recent study of customary international law has relied upon verbal State practice to support the rule that States have the right to exercise universal jurisdiction over war crimes. ${ }^{297}$ A review of this study by the U.S. rejected the ICRC's conclusion for a number of reasons. These include the practice cited by the ICRC does not support universal jurisdiction; universality envisions jurisdiction over war crimes with no relation to the prosecuting State, yet many of the national laws cited by the ICRC rely upon other principles of jurisdiction, including the protective principle, or depend upon a territorial connection to the act before a State may exercise jurisdiction; there is very little evidence of actual prosecutions of war crimes based on universal jurisdiction; and, lastly, the ICRC conflates jurisdiction under treaty obligations with customary international law. ${ }^{298}$ To this it may be added that the ICRC has assumed that war crimes are subject to universal jurisdiction by mere virtue that they are crimes under international law and that universality was "first established" in the extradite or prosecute mechanism in the 1949 Geneva Conventions. ${ }^{299}$ At the same time, in

\footnotetext{
294) See Pinochet, supra note 234, per Lord Slynn, p. 5.

295) Supra note 270.

296) E.g., see Report of the Commission on the Use of the Principle of Universal Jurisdiction by some NonAfrican States as Recommended by the Conference of Ministers of Justice/Attorneys General, supra note 7, para. 19.

297) Henckaerts and Doswald-Beck, supra note 111, vol. I, p. xlvi.

298) John B. Bellinger and William J. Haynes, 'A US government response to the International Committee of the Red Cross study Customary International Humanitarian Law', 89 International Review of the Red Cross (2007) pp. 466-471.

299) See Jean-Marie Henckaerts, 'Customary International Humanitarian Law: a response to US comments', 89 International Review of the Red Cross (2007) p. 476.
} 
order to support the actual use of universality over war crimes, the ICRC has relied upon State practice in the aftermath of World War II, including the Ablbrecht case and In re Rohrig et al., both of which, it will be recalled, were based on the protective principle. ${ }^{300}$ The other example is the scholarly work of Kre $\beta$. Kre $\beta$ has argued that universal jurisdiction has evolved over war crimes and other crimes under international law on the basis of verbal State practice; however, the basis of his argument is that war crimes have been "elevated ... to the level of crimes under international law" and that States have declared in the preamble of the Rome Statute of the ICC that "such crimes must not go unpunished". ${ }^{301} \mathrm{Kre} \beta$ also supported his argument by interpreting wholly out of context the reasoning of the U.S. Military Tribunal in The Hostages Trial. ${ }^{302}$ Kre $\beta$ 's conclusion that this must be "seen as a strong indication in favour of a customary state competence to exercise universal jurisdiction" is therefore extremely doubtful.

Perhaps the main problem with relying upon verbal State practice in support of a customary right of universal jurisdiction over war crimes is that such verbal claims are often informed, and even dependent for their validity, upon what is perceived to have been the use of universality in actual State practice in the aftermath of World War II. This verbal practice may be said to retain its validity for the formation of custom, irrespective of whether or not universal jurisdiction actually developed in the aftermath of World War II. On the other hand, it may be said to misconstrue the proper basis of jurisdiction over war crimes; this immediately becomes problematic when States attempt to go beyond mere claims and to use universal jurisdiction in actual practice, which in turn threatens vital State interests which are shared by the international community and protected by international law. Assuming for a moment that universal jurisdiction over war crimes has evolved in verbal State practice subsequently to World War II, then it could perhaps be fairly assumed that the validity of this principle and its scope and application has over several decades crystallised into a norm of customary international law. Yet the debate in recent years on universality would suggest the contrary; it is this debate to which the final part of this article will now turn.

\section{The Debate on Universal Jurisdiction}

One of the most heated debates of recent years in modern international law has been the scope and application of universal jurisdiction, which has been on the agenda of the U.N. General Assembly and the Sixth Committee since 2009, after complaints by the Group of African States that it was being used selectively and

\footnotetext{
300) Henckaerts and Doswald-Beck, supra note 297, p. 604.

301) Kreß, supra note 195, p. 574.

302) Ibid., p. 575.
} 
politically abused, particularly over African officials, by a handful of European States. ${ }^{303}$ The essence of this debate is the perceived conflict between two values of international law, namely preventing the impunity of perpetrators of international crimes on the basis of universality, on the one hand, and protecting the principles of sovereignty, sovereign equality and political independence and the immunities of incumbent State officials, on the other. ${ }^{304}$ The comments and statements made by governments illustrate the controversial, political nature of the concept of universality, and the lack of clear agreement as to its scope and application. More importantly, they also reveal great confusion as to the validity of this concept, and indeed, its very foundation, under international law. Interestingly, the African States are of the view that universal jurisdiction did not develop in State practice in aftermath of World War II. ${ }^{305}$ Nevertheless, the debate has taken as its starting point the assumption that the validity of universal jurisdiction under international law is beyond doubt, and that international law permits States to exercise universal jurisdiction over crimes under international law, including war crimes, to prevent impunity. ${ }^{306}$ Thus, the African Union, in its request for the inclusion of universal jurisdiction in the agenda of the General Assembly, having undertaken a "thorough study", declared that

[u]niversal jurisdiction is a well-established principle of international law the purpose of which is to ensure that individuals who commit grave offences, such as piracy, slavery, torture, genocide, war crimes and crimes against humanity, do not do so with impunity. ${ }^{307}$

It went on to emphasise that "the controversy surrounding the concept of universal jurisdiction is not about whether the concept validly exists, but rather about the scope of its applicability." Just one year later, however, before the Sixth Committee, the Group of African States retreated from its earlier position and asserted that:

[ $\mathrm{t}]$ here was as yet no generally accepted definition of universal jurisdiction and no agreement on which crimes, other than piracy and slavery ... it would apply ... [and that] the principle hardly existed in most domestic jurisdictions. ${ }^{308}$

\footnotetext{
303) Supra note 7.

304) S-G Report, supra note 3, paras. 108-111.

305) Report of the Commission on the Use of the Principle of Universal Jurisdiction by some Non-African States as Recommended by the Conference of Ministers of Justice/Attorneys General, supra note 7, para. 14

306) Ibid., para. 9; see also S-G Report, supra note 3, paras. 27-28, 54; AU-EU Expert Group, supra note 4, para. 9; Decision of Assembly of the African Union on the Report of the Commission on the Abuse of the Principle of Universal Jurisdiction, supra note 7, para. 3.

307) U.N. General Assembly resolution, The Scope and Application of the Principle of Universal Jurisdiction, supra note 7.

308) Cited in Yee, supra note 234, p. 524.
} 
Nevertheless, the debate on universal jurisdiction has focused almost exclusively on the scope and application of this concept. Consequently, little attention has been dedicated as to whether, and, if so, on what basis, universality is valid under international law. The broad and unsubstantiated claim first made by the African Union as to the validity of universality under international law for the prevention of impunity is common in the statements made by many other States. ${ }^{309}$ Only a few States have made statements questioning universality's validity over war crimes. ${ }^{310}$ Beyond this, however, the validity of universality has gone questioned. The same may be said of the surrounding literature, which has presupposed that universal jurisdiction is already valid in international law. ${ }^{311}$ The lack of critical analysis of universality's foundation has meant that the prevention of impunity on the basis of this principle has been elevated to a position of great importance, and even exaggerated. As has already been discussed above, in the aftermath of World War II, jurisdiction developed over war crimes under the protective principle, out of the necessity of the injured State to punish enemy war criminals; what is more, jurisdiction had nothing to do with the idea that war crimes are 'heinous', and the prevention of impunity had nothing to do with universality. Thus, the idea that international law has as one of its roles the prevention of impunity of the perpetrators of war crimes because of their 'heinous' nature and, to that end, permits States to exercise universal jurisdiction, seems to lack any foundation under customary international law. Rather, what is often described as a "movement in modern international criminal law" since the 1990s towards the pursuit preventing the impunity of perpetrators of international crimes, through the creation of ad hoc tribunals and more recently the International Criminal Court, has been misunderstood as the synonymous development of universal jurisdiction. ${ }^{312}$ This is a view which has been driven forward, in particular, by international human rights organisations ${ }^{313}$ and by works such as

\footnotetext{
309) See the comments and observations made by States at the Sixty-Fifth and Sixty-Sixth Sessions of the Sixth Committee in 2010 and 2011 respectively, <www.un.org/en/ga/sixth/65/ScopeAppUni .Juri.shtml>, 20 April 2012.

310) China, Malaysia, Sudan, ibid.

311) Julia Geneuss, 'Universal Jurisdiction Reloaded? Fostering a Better Understanding of Universal Jurisdiction. A Comment of the AU-EU Expert Report on the Principle of Universal Jurisdiction', 7 Journal of International Criminal Justice (2009) p. 951; Charles C. Jalloh, 'Universal Jurisdiction, Universal Prescription? A Preliminary Assessment of the African Union Perspective on Universal Jurisdiction', 21 Criminal Law Forum (2010).

312) See Arrest Warrant, supra note 3, per Dissenting Opinion of Judge van den Wyngaert, p. 154; per Joint Separate Opinion of Judges Higgins et al., ibid., pp. 79, 86; Germany v. Italy, supra note 238, per Dissenting Opinion of Judge Cançado Trindade; van der Wilt, supra note 277, p. 2.

313) Redress, supra note 236; Amnesty International, 'Ending Impunity: Developing and Implementing a Global Action Plan Using Universal Jurisdiction (October 2009), <www.amnesty .org/en/library/asset/IOR53/2009/en/2aaca/92d-915d-40a3-808f-46b5f2e799ae/ ior530052009en.pdf>, 15 April 2012.
} 
the International Law Association (2000), ${ }^{314}$ Institute of International Law $(2005)^{315}$ and the International Association of Penal Law (2009), ${ }^{316}$ as well as the ICRC, ${ }^{317}$ which have been taken "into account" by the debate on universal jurisdiction. ${ }^{318}$

The present debate on universality would thus appear to be wrongly postulated; while the prevention of impunity is important, there is no basis in customary international law for States to use universal jurisdiction and undermine vital State interests which are protected by international law and shared by the international community, including sovereignty, sovereign equality and political independence and the immunities of incumbent State officials. ${ }^{319}$ This certainly seems to have been the implied view of the ICJ in the Arrest Warrant. ${ }^{320}$ Similarly, States have declared in creating the ICC the importance of preventing the impunity of perpetrators of the "most serious crimes of international concern", including war crimes, but nevertheless have reaffirmed the importance of State sovereignty and the territoriality of jurisdiction by deliberately not granting to the ICC universal jurisdiction. ${ }^{321}$

It should also be noted that the debate on universality has been undertaken in almost complete isolation from other principles of extraterritorial jurisdiction recognised by international law, most importantly the protective principle; moreover, it is apparent that there is little or no understanding of the historical development of the protective principle over war crimes, which has instead been interpreted in overly-narrow terms as the protection national currency. ${ }^{322} \mathrm{With}$ these considerations is mind, it should therefore be of little surprise that the Sixth Committee has remained divided as to the scope and application of universality, and unable to reconcile this concept with vital State interests shared by the international community.

\footnotetext{
314) Supra note 1.

315) Supra note 5.

316) International Association of Penal Law, Resolution of the XVIIIth Congress, Section IV International Criminal Law, Universal Jurisdiction, <www.penal.org/?page=mainaidp\&id _rubrique=24\&id_article=95>, 20 April 2012.

317) Statement of the ICRC representative in the Sixth Committee (U.N. Doc. A/C.6/65/SR.12)

(15 October 2010); also <www.icrc.org/eng/resources/statement/united-nations-universal -jurisdiction-statement-2010-10-15.htm>, 25 April 2012.

318) S-G Report, supra note 3, para. 111.

319) See Villalpando, supra note 235, pp. 413-415.

320) Arrest Warrant, supra note 3, p. 33; see also per Separate Opinion of President Guillaume, ibid.;

per Declaration of Judge Ranjeva, ibid., p. 57; per Separate Opinion of Judge Rezek, ibid., p. 93.

321) Rome Statute, Preamble and Articles 1, 17.

322) AU-EU Expert Group, supra note 4, para. 12.
} 


\section{Conclusion}

This article has sought to challenge the common understanding that universal jurisdiction emerged over war crimes in the aftermath of World War II, and to demonstrate that jurisdiction instead represented an important development of the protective principle in customary international law. As has been shown, the protective principle was also expanded by some of the Allies, and even exercised collectively, over war crimes against the nationals of other Allied nations in one and the same war, for the punishment of a 'common enemy'. This alternative view as to the development of jurisdiction over war crimes has either been overlooked or given insufficient consideration by courts and commentators. The protective principle should therefore be regarded, it is submitted, as one of the foundations of international law. This raises important considerations as to the nature, scope and application of the protective principle in modern international law, which is little understood. There is also fundamental confusion between the protective principle and the universality and passive personality principles of jurisdiction, and the concepts of universality and extradite or prosecute. ${ }^{323}$ In that connection, the present national laws and military manuals of many States can be interpreted as providing for jurisdiction over war crimes under the protective principle and, in some cases, war crimes against the nationals of Allied nations, which reflects State practice in the aftermath of World War II. ${ }^{324}$

It is not clear the reason why the UNWCC and Lord Wright accepted uncritically the proposal made by Cowles as to the principle of universal jurisdiction over war crimes, especially as there was no basis for this under international law at that time. It may have been that universal jurisdiction was proposed by Cowles, and was readily accepted by the UNWCC and Lord Wright, in order to give the impression that the prosecution of enemy war criminals was neutral and objective, seemingly for the benefit of the international community, in anticipation of potential criticism. Indeed, the punishment of enemy war criminals and the creation of International Military Tribunals at Nuremberg and Tokyo at that time faced accusations of victors' justice and were regarded by some as contentious. ${ }^{325}$ The UNWCC was not itself a body for universal justice; it was partial, tasked with investigating war crimes by the 'enemy' against 'Allied' nationals. In any case, subsequent courts and commentators have accepted uncritically the article by

\footnotetext{
323) E.g., see AU-EU Expert Group, ibid., para. 12 and notes 88, 152 therein; Henckaerts and Doswald-Beck, supra note 111, p. 604; Geneuss, supra note 311, p. 957.

324) E.g. Armenia, Argentina, Australia, Austria, Azerbaijan, Canada, Chile, Cote d'Ivoire Ecuador, Finland, France, Ireland, Israel, Lebanon, Luxembourg, Mexico, the Netherlands, New Zealand, Russia, Slovenia, Sweden, Switzerland, United Kingdom, United States; see Henckaerts and Doswald-Beck, ibid., Chap. 44, Part B.

325) Sellars, supra note 203.
} 
Cowles and the work of the UNWCC and Lord Wright. It is notable that the U.S., which had endorsed the argument made by Cowles at that time, has since rejected the idea that war crimes are subject to universal jurisdiction; thus, the only way that the U.S. is now able to justify universality over certain other crimes is merely on the basis that they are offences under international law. ${ }^{326}$

The trial of war criminals in the aftermath of World War II undoubtedly was an important development for international criminal law, but it cannot be said to have given rise to universal jurisdiction. The development of jurisdiction over war crimes also had nothing to do with them being of a 'heinous' nature, or solely for the prevention of impunity of the perpetrators of crimes under international law. This calls into doubt the supposed theoretical foundation of universality over war crimes. These findings are important, as the advocates of universality have often gone out of their way to invoke State practice in the aftermath of World War II to support the legitimacy of universal jurisdiction under present customary international law. One of the most prominent of these is the ICRC, which has a considerable influence on shaping the views and 'verbal' practice of States, as well as legal scholarship. ${ }^{327}$ This article has also suggested that universal jurisdiction incapable of being supported as a permissive right under current international law by the concepts of jus cogens and erga omnes, or by 'verbal' State practice. Universality over war crimes has thus been accepted uncritically by courts and commentators and has been allowed to develop as a myth, a hollow concept, which is surrounded by substantial misunderstanding. This may explain why universal jurisdiction has proven to be ineffective in preventing impunity, despite this being its essential justification; and why it has remained stagnant in 'hard' State practice.

These considerations mean that some other legal basis must be found to support universal jurisdiction over war crimes, but it would not have the backing of history or State practice. It also has important implications for those seeking to expand universality over other crimes under international law. It is reasonable to call into question the validity of the debate in recent years on universality before the U.N. General Assembly and Sixth Committee, which has started from the premise that universality is valid under customary international law. It is apparent from the comments and statements made by governments that the purpose for which the concept of universality stands-the prevention of impunity-is regarded as morally commendable, and even politically appealing, and there is therefore a reluctance to object to its legitimacy; and yet, at the same time, governments have made clear that the use of universal jurisdiction against their own nationals would be an abuse of jurisdiction and a violation of international law. There is thus a

326) See 'Submission Information and Observations on the Scope and Application of the Principle of Universal Jurisdiction', <www.un.org/en/ga/sixth/65/ScopeAppUniJuri_StatesComments/ UnitedStates.pdf>, 25 April 2012.

327) Henckaerts and Doswald-Beck, supra note 111, pp. 604-605. 
crucial distinction between rhetoric, or verbal State practice, and actual State practice; this poses obvious problems for ascertaining accurate evidence of opinio juris. It is perhaps understandable why some States may find the concept of universality appealing, given that it provides them with broad prosecutorial discretion to protect their own, or their Allies, vital interests, without the burden of having to prove any nexus with the accused or the offence. It is precisely for the same reason that Anglo-American States have traditionally claimed the right to enforce international law directly over enemy war criminals. Nevertheless, the debate on universality has given insufficient attention that the concept lacks any foundation under customary international law. It should therefore be of little surprise that the Sixth Committee has to date been unable to reconcile the concept of universality with vital State interests which are shared by the international community and protected by international law, including sovereignty and sovereign equality and independence and the immunities of incumbent State officials.

The debate on universal jurisdiction has highlighted more than ever that the time may now be ripe to abandon once and for all this concept and to reconceptualise jurisdiction over war crimes as based on the protection of vital State interests which are shared by the international community. This better reflects the traditional development of jurisdictional principles under international law and, indeed, the role of international law itself. The consequence of this view is that those war crimes and other crimes under international law that do not affect the vital interests of any foreign State, and that are not prosecuted by the territorial State in which they are perpetrated, will have to be dealt with by the U.N. Security Council or the ICC. ${ }^{328}$ The Security Council and the ICC both have their limitations, which are beyond the present work. This does not, at first glance, appear to be either a satisfactory or appropriate outcome. Yet problems of this nature are nothing new in international law. Nor is it a problem that would, or should, necessarily be solved by universal jurisdiction. The perceived utopia in the aftermath of World War II was not achieved by universal jurisdiction. Rather, it is questionable whether international law should be interpreted beyond its proper role and to undermine the vital State interests shared by the international community which it seeks to protect, by permitting States with a right of universal jurisdiction. As long as the view is maintained that international law has as its role the prevention of impunity, for the protection of values of the international community, and, to that end, permits States to exercise universal jurisdiction, then it will continue to be distorted and incapable of providing for stable inter-State relations; it will also face accusations of being selective, effective in some situations and impotent in others, and incapable of providing universal justice.

328) The same point has been made by the Spanish Supreme Court in the Guatemalan Generals case, supra note 270. 